\title{
1 Soil organic matter in dryland ecosystems
}

2

3 César Plaza ${ }^{\text {a, b, c, * , Gabriel Gascó }}{ }^{\mathrm{d}}$, Ana M. Méndez ${ }^{\mathrm{e}}$, Claudio Zaccone ${ }^{\mathrm{f}}$, and Fernando T. 4 Maestre $^{\mathrm{b}}$

5

$6{ }^{a}$ Instituto de Ciencias Agrarias, Consejo Superior de Investigaciones Científicas, Serrano 115

7 bis, 28006 Madrid, Spain

8 b Departamento de Biología y Geología, Física y Química Inorgánica, Escuela Superior de

9 Ciencias Experimentales y Tecnología, Universidad Rey Juan Carlos, 28933 Móstoles, Spain

$10{ }^{\mathrm{c}}$ Center for Ecosystem Science and Society, Northern Arizona University, Flagstaff, Arizona

1186011, USA

12 d Departamento de Edafología, ETSI Agrónomos, Universidad Politécnica de Madrid, Ciudad

13 Universitaria, 28004 Madrid, Spain

14 e Departamento de Ingeniería de Materiales, ETSI Minas, Universidad Politécnica de Madrid, 15 Ríos Rosas 21, 28003 Madrid, Spain

$16{ }^{\mathrm{f}}$ Department of the Sciences of Agriculture, Food and Environment, University of Foggia, via 17 Napoli 25, 71122 Foggia, Italy

18

19 * Corresponding author. Tel.: +34 917452500 Ext. 950191

20 E-mail address: cesar.plaza@csic.es (C. Plaza).

21

22 


\section{Abstract}

25 Drylands are regions with low rainfall, high temperatures and very high evapotranspiration, as 26 well as limited plant biomass production. Covering over $45 \%$ of the Earth's land surface and 27 being inhabited by more than $35 \%$ of the world population, drylands are of paramount importance for global sustainability. Among the many factors that influence the ability of 29 drylands to provide essential ecosystem services, soil organic matter deserves special attention. 30 This chapter provides an overview of the quantity of soil organic matter in dryland ecosystems, 31 the main factors regulating its formation and conservation, its vulnerability to ongoing global 32 changes, and existing options to preserve or even enhance this essential natural resource.

34 Keywords: Aridity; C cycle; C sequestration; Climate change; Drylands; Global Change; 35 Grazing; Organic amendments; Soil organic matter; Tillage.

\section{Introduction} average precipitation, resulting in a water deficit that limits net primary production (Safriel et al.,

42 2005). More precisely, the United Nations Environment Program (UNEP) defines drylands as 43 terrestrial areas where the aridity index (AI), or the ratio of total annual precipitation to potential 44 evapotranspiration (evaporation from soil and transpiration by plants), is less than 0.65 (UNEP, 1997). Based on the AI, drylands are further divided into hyperarid (AI less than 0.05), arid (AI 
47 from 0.5 to 0.65 ). The United Nations Convention to Combat Desertification (UNCCD) uses this 48 classification, but addresses specifically only arid, semiarid, and dry subhumid areas as drylands 49 for its purposes, excluding hyperarid areas (UNCCD, 1994). Instead of using the AI, the United 50 Nations Food and Agriculture Organization (FAO) developed an index termed "length of 51 growing period" (LGP) to identify the crop cultivation potential of land. The LGP, referring to 52 the number of days in a year when temperature and soil moisture allow plant growth, is also used 53 to classify general moisture regimes (IIASA/FAO, 2012). Areas with an LGP of 0 , less than 60 , 54 from 60 to 119 , and from 120 to 179 days are classified as hyperarid, arid, dry semiarid, and 55 moist semiarid, respectively, which together correspond closely to the areas defined as drylands 56 in the World Atlas of Desertification (FAO, 1993, 2004; IIASA/FAO, 2012).

57 Dryland ecosystems are of paramount significance both in terms of their extension and the 58 human population they support. In particular, drylands cover over $45 \%$ of the Earth's land 59 surface, or about 6.7 billion hectares (Prăvălie, 2016), more than $70 \%$ of which is occupied by 60 developing countries (FAO, 2004; Safriel et al., 2005; UN Environmental Management Group, 61 2011; Prăvălie, 2016) (Figure 1). Hyperarid, arid, semiarid, and dry subhumid regions account 62 for about 13, 31, 36, and 20\% of this area, respectively (Prăvălie, 2016). Most drylands can be ascribed to four biomes of decreasing aridity: deserts, grasslands, Mediterranean scrublands, and woodlands (Safriel et al., 2005). Of the global dryland area, approximately $65 \%$ is used as rangelands and $25 \%$ as cropland (Safriel et al., 2005). More than 2 billion people, or more than one third of the human population, live in drylands, and about $90 \%$ of these live in developing countries (Safriel et al., 2005; Middleton et al., 2011).

Soils make up an essential part of drylands, as in any other terrestrial ecosystem, as they constitute the medium for plant growth, provide a habitat for a wide range of organisms, regulate 
water fluxes, and store C. The most common soils in drylands are Entisols (2.3 billion hectares)

71 and Aridisols (2.1 billion hectares), followed by Mollisols, Alfisols, and Vertisols (FAO, 2004).

72 Compared to humid-region soils, those in drylands are commonly characterized by low organic

73 matter and nutrient contents, frequent water stress, coarse to medium texture, moderate to high

74 base saturation, slightly acid to alkaline surface $\mathrm{pH}$, accumulation of calcium carbonate, shallow

75 to moderate profile development, and low biological activity (Dregne, 1976; Skujins, 1991).

76 These properties result in inherently low fertility (Lal, 2004a).

77 Among the many factors that impact the quality and fertility of soils in drylands and their

78 ability to provide essential ecosystems services, soil organic matter deserves special attention.

79 This is because soil organic matter in drylands constitutes a huge global $\mathrm{C}$ reservoir and

80 influences almost all physical, chemical, and biological soil properties and processes in these

81 ecosystems (Lal, 2004a, 2009). Among other benefits, soil organic matter promotes the

82 formation of aggregates with mineral particles, which improves soil structure, porosity, and

83 moisture holding capacity, thus reducing the severity of water scarcity and protecting soils from

84 erosion and compaction. Also, soil organic matter contributes markedly to the soil acid-base

85 buffering capacity and represents an important source of plant nutrients. Furthermore, soil

86 biological diversity and activity are also strongly related to soil organic matter as a major source

87 of food for a variety of organisms (e.g., Paul et al., 1997; Bot and Benites, 2005; Paul, 2016).

88 This chapter provides an overview of the amount of soil organic matter stocks stored in

89 dryland ecosystems. It also explores the processes and factors affecting the balance between

90 accumulation and loss of soil organic matter, its vulnerability to global change, and the main

91 options available for its preservation and enhancement. 
2. Soil organic matter stocks in drylands

Soil organic matter represents one of the largest active $\mathrm{C}$ reservoirs on Earth and thus plays a

97 significant role in the global $\mathrm{C}$ cycle with implications for the mitigation or exacerbation of 98 climate change (Batjes, 1996; Jobbággy and Jackson, 2000; Schmidt et al., 2011; IPCC, 2013). In particular, while the atmosphere and global vegetation are estimated to contain 829 and 520 Pg of C, respectively (IPCC, 2013), global soil organic C mass is thought to be $1301 \mathrm{Pg}$ within 101 the top $1 \mathrm{~m}$, and about $2800 \mathrm{Pg}$ when deeper soil layers are considered. This estimation is based on the Harmonized World Soil Database (HWSD) v.1.2 (FAO/IIASA/ISRIC/ISSCAS/JRC, 103 2012; Köchy et al., 2015), corrected for the latest northern permafrost region inventory, which 104 estimates that permafrost soils store $472 \mathrm{Pg}$ of organic $\mathrm{C}$ in the top $1 \mathrm{~m}, 1035 \mathrm{Pg}$ in the top $3 \mathrm{~m}$, 105 and 1330-1580 Pg in the known pool of terrestrial permafrost (Hugelius et al., 2014; Schuur et 106 al., 2015).

Globally, the largest soil organic C concentrations and stocks are in wetlands and peatlands, 108 generally in permafrost and tropical regions (Köchy et al., 2015). Soil organic C concentrations 109 in drylands are markedly smaller, often less than $0.5 \%$ of the soil mass, resulting in typical 110 densities of 0 to $15 \mathrm{~kg} \mathrm{~m}^{-2}$ (Lal 2004a). However, due to the vast extension of dryland 111 ecosystems, the total amount of organic $\mathrm{C}$ stored in dryland soils is significant for the global C 112 cycle (Lal, 2004a). In particular, dryland soils are estimated to contain $431 \mathrm{Pg}$ of organic C 113 (Safriel et al., 2005), which represents about 33\% of the global soil organic C reserves in the 114 uppermost $1 \mathrm{~m}$. Hyperarid and arid soils hold $113 \mathrm{Pg}$, whereas semiarid and dry subhumid soils 115 store $318 \mathrm{Pg}$. In addition to organic C, dryland soils are estimated to hold $916 \mathrm{Pg}$ of inorganic C, 
116 mainly as calcium carbonate, which accounts for $97 \%$ of the inorganic C stocks in the world's

117 soils. Hyperarid and arid soils contain 732 Pg while semiarid and dry subhumid soils have 184

118 Pg (Safriel et al., 2005) (Figure 2).

119 As in the rest of terrestrial ecosystems, knowledge of the total soil organic $\mathrm{C}$ stock and its 120 spatial distribution in drylands is essential to understand their vulnerability to global change and 121 to develop strategies to recover, preserve, or enhance the services provided by their ecosystems.

122 The current estimates of organic C stocks in dryland soils outlined above are still highly 123 uncertainprobably not accurate, being typically derived from soil databases that may 124 underrepresent some regions (Köchy et al., 2015). Moreover, soil profile data are not collected 125 with a consistent methodology and generally do not include soil layers deeper than $1 \mathrm{~m}$ 126 (Darrouzet-Nardi, 2013). Nonetheless, most soil C in drylands is believed to reside in topsoil 127 (Ciais et al., 2011), making it highly vulnerable to climate change and erosion process.

\section{Natural factors affecting soil organic matter in drylands} production, and losses, which occur mainly through in situ decomposition and respiration, but 134 also through leaching, volatilization, erosion, and burning (Schulze and Freibauer, 2005). 135 According to the latest concepts, plant material entering the soil is continuously processed by the 136 decomposer community, producing fragments of smaller size with a concomitant surge in 137 microbial byproducts (Plaza et al., 2013; Courtier-Murias et al., 2013; Lehmann and Kleber, 138 2015) (Figures 3). Soil organic matter decomposition is modulated by a number of 
139 interconnected environmental, physical, chemical, and biological controls, such as temperature, 140 moisture, activity and composition of microbial community, and organomineral interactions 141 (Sollins et al., 1996; Six et al., 2002; Von Lützow et al., 2006; Schmidt et al., 2011). Freezing 142 temperatures and high moisture content $\left(\right.$ low $\left.\mathrm{O}_{2}\right)$ help preserve soil organic matter (climatic and 143 environmental protection), as well as its association with aggregates (physical protection) and 144 mineral surfaces (chemical protection) (Torn, 1997, 2009; Trumbore, 2009; Plaza et al., 2012, 145 2013) (Figure 4). During the degradation of plant material, organic substances are accumulated 146 and protected from decomposition within aggregates and on mineral surfaces, limiting the access 147 and action of decomposers (Golchin et al., 1994; Plaza et al., 2012, 2013; Courtier-Murias et al., 148 2013; Lehmann and Kleber, 2015).

149 More generally, according to the classic work by Hans Jenny (1941), soil organic matter 150 stocks in drylands, like any other soil property in a given ecosystem, is a function of a number of 151 soil forming factors, including climate, organisms (vegetation and soil biota), parent material, 152 relief, and time. The main distinctive soil forming factors that drive soil organic matter storage in 153 drylands are climate and vegetation. These state factors govern the balance of soil organic matter 154 by influencing both the quantity and quality of plant input and the rate of decomposition. They 155 also strongly influence the weathering and reactivity of soil minerals (thus affecting protective 156 organomineral interactions), the structure and metabolic activity of the microbial community, 157 and erosion as well as fire processes (Morgan, 2005; Lehmann et al., 2014).

158 Climate is the dominant factor explaining the low organic matter contents in dryland soils. 159 By definition, drylands not only receive low precipitation, which limits plant production and 160 organic matter inputs into the soil, but also have high temperatures, which encourage 161 decomposition. In general, all else equal, regions with higher aridity tend to have smaller soil 
162 organic matter stocks than do wetter regions. Furthermore, the rainfall regime of many dryland 163 regions is characterized by events of short duration and high intensity (Nicholson, 2011), which 164 favors soil organic matter losses by runoff and erosion (Martínez-Mena et al., 2002). Also, the 165 low precipitation and high temperature increase the risk of wildfires in drylands (Middelton and 166 Sternberg, 2013). Burning diminishes soil organic matter stocks over the short term; however, 167 over the long term, wildfires might cause opposite effects because of the formation of organic 168 compounds highly resistant to decomposition (Johnson and Curtis, 2001).

169 Vegetation affects soil organic matter stocks in drylands in several ways. Because of climate, 170 plant productivity in drylands is low and therefore so is the rate of plant $\mathrm{C}$ inputs into the soil. 171 However, the low water and nutrient availability generally favor other plant traits that help slow 172 down decomposition and build up soil organic matter, such as poor-quality litter and a high root173 to-shoot ratio that favors organic C allocation and protection deep into the soil (De Deyn et al., 174 2008). The spatial organization of vegetation, which organizes into discrete plant patches 175 surrounded by areas devoid of vascular vegetation (Berdugo et al., 2017), is also relevant to soil 176 organic matter stocks, particularly to their spatial distribution within dryland landscapes (Figure 177 5). The length of the growing season, which is highly variable in drylands, is also thought to 178 have a significant influence on soil organic matter content (Lal, 2004a).

179 In addition to vegetation, biological soil crusts are a major biotic factor in organic $\mathrm{C}$ fixation 180 in dryland soils. Biological soil crusts, or biocrusts, are communities of organisms dominated by 181 lichens, mosses, bacteria, and fungi, inhabiting the soil surface (Belnap and Lange, 2003) (Figure 182 6). These communities have been found to be able to take up significant amounts of $\mathrm{C}$ and $\mathrm{N}$ 183 from the atmosphere by photosynthesis and $\mathrm{N}$ fixation (Elbert et al., 2012), thus being an 184 important pool and source of organic inputs into the soil and having a major role in soil 
185 respiration in dryland ecosystems (Castillo-Monroy et al., 2011). Elbert et al. (2009) estimated

186 the net uptake of $\mathrm{C}$ by biological soil crusts in drylands at $16 \mathrm{~g} \mathrm{~m}^{-2} \mathrm{yr}^{-1}$, which corresponds to a 187 total of approximately $1.0 \mathrm{Pg} \mathrm{yr}^{-1}$ for the global dryland area. Biocrusts are also known to protect 188 soil from wind and water erosion, and thus from C loss, by strengthening soil structure through 189 the interaction with mineral particles and formation of aggregates (Eldridge and Leys, 2003; 190 Bowker, 2007; Belnap, 2013).

191 The abundance and strength of the organo-mineral interactions, and thus the physical and 192 chemical protection of soil organic matter from decomposition, are thought to be lower in 193 dryland soils than in soils of humid regions (Kleber et al., 2015). This is because water largely 194 controls the weathering and formation of reactive sites on minerals needed to create organo195 mineral associations. While wet conditions promote plant production, low $\mathrm{pH}$ conditions, soil 196 weathering, and the formation of strong inner-sphere bonds between organic matter and mineral 197 surfaces, energetically weaker outer-sphere complexation and H-bonds between organic matter 198 and minerals are thought to dominate in dryland soils because of the lower moisture (Kleber et 199 al., 2015).

200

201

\section{Management activities affecting soil organic matter in drylands}

Effects of grazing on soil organic matter in drylands

205

Livestock grazing is the main land use type in dryland regions and the primary livelihood for many of their inhabitants (Lal, 2004a). Grazing is known to largely affect the structure, 
composition, and functioning of dryland ecosystems (Eldrige et al., 2016; Maestre et al. 2016; Gaitán et al., 2017), including their capacity to fix and store soil organic matter. Changes in soil organic matter stocks with grazing is mainly a function of its effects on net primary production (Piñeiro et al., 2010). Even though livestock may return a large proportion of nutrients and organic matter in the form of dung and urine (Haynes and Williams, 1999), this effect is likely not strong enough at a large scale to reinforce soil fertility in low-productive ecosystems (Bardgett and Wardle, 2003), such as drylands, and aboveground plant biomass is often reduced significantly by grazing. Using a large database from Australian rangelands, Eldrige et al. (2016) recently reported reductions of plant biomass by $40 \%$ and plant and litter cover by $25 \%$ after grazing, with more profound effects in drier environments and noticeable effects even at low grazing intensities. Using the same large set of records, Maestre et al. (2016) found that grazing, even at low intensity, negatively affected the $\mathrm{C}$ content and reported average reductions of approximately $8 \%$. In addition to a decrease in aboveground plant inputs into the soil, livestock often increases soil compaction through trampling, thereby reducing water infiltration and availability to plants while encouraging runoff and soil erosion, thus further contributing to soil organic matter losses (Piñeiro et al., 2010; Eldridge et al., 2016). Intensive grazing has also been found to adversely affect soil organic matter stocks by reducing the cover, biomass, and diversity of the biological soil crusts through trampling and burial (Warren and Eldridge, 2003; Thomas, 2012). Increases in $\mathrm{C}$ inputs into the soil from greater root biomass due to changes in plant $\mathrm{C}$ allocation or species abundance, on the other hand, have been suggested to partially offset soil organic matter loss in drylands (Piñeiro et al., 2010).

\section{Effects of cultivation on soil organic matter in drylands}


232 Cultivation is the second most widespread use of drylands (Safriel et al., 2005). The conversion of natural ecosystems to croplands is well known to cause significant losses of soil 234 organic matter (Matson et al., 1997), and has been responsible for a large proportion of the 235 global anthropogenic $\mathrm{CO}_{2}$ emissions (Lal, 2004b; IPCC, 2013). Meta-analysis results estimate 236 global soil $\mathrm{C}$ stock losses at $42 \%$ when converting from native forest to crop and at $59 \%$ from 237 pasture to crop (Guo and Gifford, 2002). As throughout the rest of the globe, the expansion and 238 intensification of cultivation in drylands have led to a substantial depletion of soil organic matter 239 stocks, concomitantly with more severe nutrient depletion and soil erosion. For example, it has 240 been estimated that cropping of Australian semiarid regions has resulted in long-term losses of 241 soil organic matter often exceeding 60\% of the initial content (Dalal and Chan, 2001).

242 In general, the loss of soil organic matter with conversion to permanent agriculture can be 243 attributed to decreased input rates of plant-derived organic matter and increased decomposition 244 rates. Agricultural crops are harvested and typically leave less organic matter belowground than 245 does native vegetation (Post and Kwon, 2000). The rate and amount of organic matter loss 246 depend not only on natural factors, such as climate and soil properties, but also on the specific 247 cropping system. Farming methods that have particularly exacerbated the loss of soil organic 248 matter in drylands include the use of conventional intensive tillage and removal of crop residues 249 (McLeod et al., 2013).

250 Conventional intensive soil tillage, used for weed control and seedbed preparation, reduces 251 soil organic matter stocks by increasing soil aeration and facilitating the access of decomposers 252 to organic substrates, thus accelerating decomposition rates (I. Haller, personal communication) 253 (Figure 7). More specifically, soil tillage is thought to increase macroaggregate turnover, thereby 
254 inhibiting the formation of microaggregates within macroaggregates in which particulate organic 255 matter is stabilized over the long term (Six et al., 1998, 1999, 2000). It has also been proposed 256 that the increased macroaggregate turnover may inhibit not only microaggregate formation and 257 thereby the physical protection of crop-derived particulate organic matter, but also the interaction 258 between mineral particles and microbial material that results in the formation of very stable 259 organo-mineral complexes (Plaza et al., 2013). By disturbing the soil structure, tillage also 260 makes soil organic matter more vulnerable to erosion losses.

\section{Vulnerability of soil organic matter in drylands to global change}

Humanity has a dominant and growing influence on the structure and functioning of all ecosystems on Earth (Vitousek et al., 1997). Because of their inherently low fertility and

267 vegetation cover, dryland ecosystems are particularly vulnerable to human activities and global environmental change drivers, including global warming, invasion of alien species, and increased $269 \mathrm{~N}$ deposition, which have profound social and economic implications (Reynolds et al., 2007).

271 Economic and Social Affairs of the United Nation Secretariat (UN-DESA-PD, 2015), the world 272 population continues to grow and is projected to reach 8.5 billion by 2030, 9.7 billion in 2050 273 and 11.2 billion in 2100. Most of the projected increase will occur in developing countries and in 274 dryland regions. A rapidly increasing population will demand more food and livestock 275 production (Thornton et al., 2010; Foley et al., 2011; Tilman et al., 2011). This will put more 276 pressure on drylands, as cropland use intensifies and pastures are expanded, negatively affecting 
277 soil organic matter stocks as described above. In fact, population growth is arguably the most

278 critical challenge facing drylands to avoid further degradation and desertification.

279

280

Vulnerability of soil organic matter to climate change in drylands

281

282

Continued anthropogenic emissions of greenhouse gases, particularly $\mathrm{CO}_{2}$, will spur further

283

rises in global mean temperatures over the 21 st century (IPCC, 2013). By the end of this century,

284 dryland area is projected to increase by $23 \%$ under the current path of $\mathrm{CO}_{2}$ emissions and global 285 warming (Representative Concentration Pathway RCP8.5) and by 11\% under a scenario of

286 intermediate emissions in which total radiative forcing is stabilized shortly after 2100 (RCP4.5),

287 relative to the 1961-1990 baseline (Huang et al., 2016). In other words, by 2100, 56\% (RPC8.4)

288 or $50 \%$ (RPC4.5) of the total land surface area is expected to be covered by drylands (Huang et

289 al., 2016). Dryland expansion and humid region shrinkage will reduce global plant production,

290 which will in turn diminish global soil organic matter stocks and augment $\mathrm{CO}_{2}$ in the 291 atmosphere.

292 In drylands, temperatures are expected to rise more than in humid regions, with $4{ }^{\circ} \mathrm{C}$ 293 increases projected in some areas (IPCC, 2013). Precipitation patterns will be altered, extreme 294 events such as droughts and heat waves will become more frequent, and the degree of aridity 295 experienced by drylands will increase (IPCC, 2013; Fu and Feng, 2014; Cook et al., 2015; 296 Huang et al., 2016). All these interwoven factors are expected to reduce the overall plant cover 297 (Delgado-Baquerizo et al., 2013) and the abundance and diversity of soil bacteria and fungi 298 (Maestre et al., 2015), exerting negative consequences on C cycling and storage (Delgado299 Baquerizo et al., 2016). Furthermore, the expected increases in aridity with climate change are 
expected to negatively affect the abundance, composition, and diversity of biocrusts, thereby compromising their organic C sink capacity (Maestre et al., 2013; Ferrenberg et al., 2015).

Vulnerability of soil organic matter to vegetation shift in drylands

Vegetation shifts, and particularly the invasion of native grasslands by woody species (shrub encroachment) or exotic grasses, is a widespread phenomenon long documented in many dryland areas (Archer, 1994; Van Auken, 2000; Biedenbender et al., 2004; Maestre et al., 2009; Brazier et al., 2014). A number of studies suggest that plant invasions of grasslands in dry environments tend to boost the soil organic $\mathrm{C}$ content in the absence of human and natural disturbance (Jackson et al., 2002; Barger et al., 2011), while a global meta-analyses reported significant increases in total and organic soil $\mathrm{C}$ with shrub encroachment (Eldridge et al., 2011). In North American drylands, trends of soil organic $\mathrm{C}$ accumulation with woody plant encroachment were found not to be coupled to aboveground net primary production, which tended to decrease in arid regions and to increase in semiarid and subhumid regions (Barger et al., 2011). Changes in vegetation have often been reported to be accompanied by greater run-off and erosion, which may significantly offset gains in plant $\mathrm{C}$ inputs and lead to net soil organic matter losses (Turnbull et al., 2010; Brazier et al., 2014; Puttock et al., 2014). For example, recent studies across a shrub encroachment gradient in the southwestern United States indicated that soil organic C stored beneath the vegetation increased relative to that of bare soil areas as the grass cover became sparser and shrubs became more established in the landscape (Brazier et al., 2014; Puttock et al., 2014). In this case, there was more heterogeneity of soil organic $C$ with encroachment from a more homogeneous distribution under grass to a patchy distribution under shrubs; and this spatial 
323 heterogeneity made soil and soil organic $\mathrm{C}$ more susceptible to erosion from areas between 324 shrubs.

Vulnerability of soil organic matter to $N$ deposition in drylands atmosphere (Gruber and Galloway, 2008). This excess of $\mathrm{N}$ is not only contributing to global warming but is also resulting in heavier atmospheric deposition of $\mathrm{N}$ in terrestrial ecosystems worldwide (Gruber and Galloway, 2008). Plant growth in drylands, as in most ecosystems, is naturally N limited (Waldrop et al., 2004; Maestre et al., 2016; Ochoa-Hueso et al., 2016). The addition of $\mathrm{N}$ may thus enhance plant growth and organic matter inputs (Maestre et al., 2016;

335 Ochoa-Hueso et al., 2016). Increased $\mathrm{N}$ deposition, however, can also favor fast-growing plant 336 species at the expense of the slow-growing ones and thereby reduce native plant diversity 337 (Bobbink et al., 2010; Lan and Bai, 2012). Other effects of $\mathrm{N}$ deposition that may alter the ability 338 of drylands to store soil organic matter include soil acidification, stronger aluminum toxicity, and 339 changes in soil microbial composition, biomass, and activity (Bardgett, 2005; Ochoa-Hueso et 340 al., 2011). In general, $\mathrm{N}$ enrichment can stimulate cellulolysis and labile organic matter 341 decomposition, while suppressing the ligninolytic activity of fungi (Fog, 1988). The structure 342 and function of biocrusts are also reportedly affected by $\mathrm{N}$ deposition, the most significant 343 responses being reductions in photosynthesis rates and shifts in cyanobacteria community 344 (Ochoa-Hueso et al., 2013). Although the available data are scarce, all these potential operating 345 factors identified in the literature suggest that the effects of $\mathrm{N}$ deposition for soil organic matter 
346 storage in non-agricultural drylands may be highly context dependent. Soil organic C content

347 declines along a gradient of $\mathrm{N}$ deposition in low-productivity semiarid Mediterranean areas

348 (Ochoa-Hueso et al., 2013), while soils of other different ecosystems subject to elevated $\mathrm{N}$

349 additions appear to be soil organic matter sinks (Lloyd, 1999; Zak et al., 2016).

350 As a whole, ample evidence implies that the ongoing global environmental change will 351 substantially affect the structure and function of dryland ecosystems, including their ability to 352 store soil organic matter. It is important to note that global change phenomena occur 353 simultaneously, and therefore their effects on ecosystems may lead to highly significant 354 interactions between them (Bardgett, 2005). However, little is known about the magnitude of 355 these interactions and how they might affect soil organic matter stocks in drylands, albeit there is 356 evidence of biological feedbacks between climate change and changes in biocrust communities 357 can alter them (Maestre et al., 2013).

\section{Practices to restore, preserve, and augment soil organic matter in drylands} provide key services needed for global sustainability, including food and wood production, $\mathrm{CO}_{2}$

364 fixation and soil stability (Haygarth and Ritz, 2009; see chapter by Masciandaro et al. in this 365 book). Yet dryland soils have been a historic source of $\mathrm{CO}_{2}$ emissions to the atmosphere and 366 have lost massive amounts of their native soil organic matter contents due to land management 367 practices, degradation, and desertification. In the dryland ecosystems of West Asia and North 368 Africa alone, which represent roughly $25 \%$ of the global dryland area, the historic organic C loss 
369 is thought to have been between 6 and $12 \mathrm{Pg}$ (Lal, 2001a). Desertification has caused the loss of 37020 to $30 \mathrm{Pg}$ of $\mathrm{C}$ globally (Lal, 2001b, 2004a). The magnitude of this loss shows the potential

371 and the urgent need to develop strategies to restore, preserve, or increase soil organic matter in

372 drylands, as these strategies may help bolster productivity, prevent erosion, and degradation, and

373 mitigate climate change, with substantial local and global societal, economic, and environmental

374 benefits. Soil organic matter contents can be built up through management practices that increase 375 organic inputs intothe soil and decrease organic matter decomposition, erosion, and leaching, or 376 both (Lal., 2004a, 2009). These practices include cropland conversion to grassland and 377 afforestation, improved grazing regime, and improved farming management, such as using 378 organic amendments, mineral $\mathrm{N}$ fertilization, cover crops, crop rotations, shifting from 379 conventional tillage to conservation tillage practices, and improving water use efficiency (Lal, 380 2004a, 2004c) (Figure 8). The potential of increasing soil C in drylands is estimated to be about $38160-70 \%$ of the historic C loss in 25 to 50 years (Lal, 2001a, 2001b, 2004a).

382

\section{Cropland conversion to grasslands and afforestation}

Land conversion from natural to agricultural ecosystems has been the main cause for the 386 historic depletion of soil organic matter stocks (Lal, 2004c). There is abundant evidence that, in 387 drylands, shifts from crop cultivation to grass or tree based systems, including conversion to 388 pasture and agroforestry production systems, can help in the recovery, at least partially, of the 389 historic soil organic matter pools (Lal, 2001a, 2001b, 2004a). In a semiarid watershed in northern 390 Ethiopia, for example, compared to rainfed crop production, soil organic C stocks to $30 \mathrm{~cm}$ 391 increased by 52\% with based fruit production, $60 \%$ with agroforestry based crop production, 
$392143 \%$ with silvopasture, and $227 \%$ with open communal pasture after 50 years after land use 393 conversion (Gelaw et al., 2014). In the Highveld of semiarid South Africa, with the use of a 394 chronosequence and modeling approach, soil organic $\mathrm{C}$ stocks to $20 \mathrm{~cm}$ deep were estimated to 395 increase after cropland conversion to permanent grassland for use as pasture, reaching maximum 396 values after 10 to 95 years, which were $30 \%$ to $94 \%$ higher than in adjacent arable soils, but $28 \%$ 397 to 53\% lower than in native grasslands (Preger et al., 2010). These latter results strongly suggest 398 that, in native grassland soil, organic matter loss cannot be entirely recovered after land use 399 change.

400 Soil organic matter accrual after afforestation depends on a number of factors, such as 401 previous land use, plantation age, soil properties, tree species, and climate (Langanière et al., 402 2010; Berthrong et al., 2012; Li et al., 2012). In the long term, C accumulation is likely to be 403 greater in croplands than in grasslands, and in pastures than in natural grasslands, with broadleaf 404 than with coniferous species, in clay-rich than in coarse-textured soils, and in warmer and dryer 405 than in cooler and wetter regions (Langanière et al., 2010; Berthrong et al., 2012; Li et al., 2012). 406 For instance, in the semiarid Loess Plateau of China, cropland afforestation increased soil 407 organic $\mathrm{C}$ stocks after an initial depletion period, with higher relative gain as precipitation 408 declined (Chang et al., 2014). In many dryland ecosystems, the impacts of afforestation on soil 409 properties and $\mathrm{C}$ sequestration also highly depend on the planting technique employed. In 410 Southeastern Spain, plantations of tree species such as Pinus halepensis frequently show 411 enhanced runoff and soil losses when compared to adjacent natural shrublands, as well as limited 412 improvement in most physico-chemical properties, which rarely reach the values shown by 413 natural shrublands even 40 years after planting (Maestre and Cortina, 2004). 
Intensive livestock grazing has been shown to affect the structure, composition, and

418 functions of dryland ecosystems, including their ability to store soil organic matter mainly by

419 reducing plant cover, decreasing plant-derived organic inputs, and destroying biocrusts (Thomas,

420 2012; Eldrige et al., 2016). In general, improved practices aimed at lowering grazing intensity,

421 alleviating soil disturbance, and lengthening soil and plant recovery time can help reduce soil

422 organic matter loss and restore $\mathrm{C}$ sequestration capacity (Thomas, 2012). In semiarid grasslands

423 of South Africa, soil organic C stocks to $20 \mathrm{~cm}$ in farms with rotational grazing were higher by a

424 factor of 1.4 relative to areas with continuous grazing, commonly overstocked and with shorter

425 soil and vegetation resting times (Kotzé et al., 2013). Destocking grazed Australian semiarid 426 shrublands for two decades increased soil C stocks by about $6.5 \mathrm{Mg} \mathrm{ha}^{-1}$ (Daryanto et al., 2013).

427 Selective grazing can also reduce soil organic matter loss by promoting plant traits connected to 428 slow C turnover (Bardgett and Wardle 2003; De Deyn et al., 2008). Controlled stubble grazing 429 after crop harvest vs. removal of crop residues is another management option to reduce erosion 430 and maintain or build up organic matter in dryland soils (FAO, 2004; Lal, 2004b; Blanco-Canqui 431 et al., 2016; Stavi et al., 2016).

432

Improved management practices in croplands

Organic amendments. The application of organic amendments to the soil is a longestablished management practice proven to be highly effective to replenish and augment soil

437 organic matter in croplands (Ogle et al., 2005; Senesi et al., 2007; Paustian., 2014). Organic 
438 amendments can build up soil organic matter both directly by adding organic $\mathrm{C}$ and indirectly by 439 enhancing $\mathrm{C}$ inputs from crop residues through improving total plant biomass production 440 (Fernández et al., 2009) (Figure 9). Traditional organic products that have been used for 441 thousands of years include crop residues and animal manures. Organic amendments typically 442 originate from waste materials subjected to appropriate treatments, such as composting. These 443 treatments aim to destroy pathogens, eliminate phytotoxic substances, and stabilize the organic 444 matter components, so that, once in soil, they decompose relatively slowly (Senesi et al., 2007). 445 Long-term experiments have shown that the application of organic amendments, such as crop 446 residues, manure, sewage sludge, and municipal solid waste compost, can increase soil organic 447 matter contents by up to $90 \%$ (Diacono and Montemuro, 2010), and the gains in drylands can be 448 long-lasting even after just a single application (Bastida et al., 2008).

449 Among the wide range of organic amendments available to farmers, biochar has recently 450 emerged as a highly promising product for climate change mitigation. Biochar is made by the 451 pyrolysis of biomass, and biochar $\mathrm{C}$ is believed to form very stable structures, which can be 452 stored in soils for much longer than the biomass C from which it originates (Lehmann, 2007; 453 Lehmann and Joseph, 2015) (Figure 10). The typically high $\mathrm{pH}$ values of biochar might be a 454 limiting factor for its application in highly alkaline dryland soils. Nonetheless, under semiarid 455 conditions biochar may also help stabilize organic C from other amendments co-applied to soil 456 by promoting organo-mineral associations (Plaza et al., 2016) (Figure 11).

457 Mineral fertilization. The correct application of mineral fertilizers, particularly $\mathrm{N}$ fertilizers, 458 increase crop production and plant-derived organic inputs into the soil. These inputs, however, 459 may not be substantial enough to offset organic matter losses through mineralization in drylands, 460 and current evidence suggests that it is particularly important to combine mineral fertilization 
461 with other recommendable agricultural practices to efficiently increase soil organic C stocks. For 462 example, repeated mineral fertilization for 26 years at an arid site in China did not affect the total 463 soil organic matter contents (Hai et al., 2010). Similarly, in a 7-year field experiment in 464 northwestern China under arid conditions, mineral fertilization had little effect on soil organic 465 matter contents, but improved the performance of organic manure (Yang et al., 2016). Practices 466 that retain crop residues in the field have been shown to benefit particularly from mineral 467 fertilization for soil organic matter accrual (Naab et al., 2015).

468 Crop rotation. Compared to the practice of growing the same crop for many years on the 469 same field (monoculture), crop rotation avoids the disproportional depletion of nutrients and 470 controls weeds as well as pests, thereby improving above- and belowground biomass production. 471 Growing different crops, especially crops that produce large amount of residues, can thus 472 augment soil organic matter stocks by increasing organic matter inputs into the soil (West and 473 Post, 2002; Ogle et al., 2005; Palm et al., 2014). For example, an experiment conducted at a 474 semiarid site in the Argentine Pampa showed 3\% more soil organic C stocks to $100 \mathrm{~cm}$ after 15 475 years under a soybean-maize alternation than under a soybean monoculture (Alvarez et al., 476 2014).

477 Cover crops. A cover crop, consisting of plants planted between cash crops to conserve and 478 enrich the soil, can provide multiple benefits, such as preventing soil erosion, storing nutrients, 479 suppressing weeds, controlling pests and diseases, and improving soil structure, among others. In 480 a recent review, Blanco-Canqui et al. (2015) showed that cover crops can boost soil organic C 481 stocks from 0.01 to $0.1 \mathrm{~kg} \mathrm{~m}^{-2} \mathrm{yr}^{-1}$, depending on factors such as initial soil organic matter 482 content, biomass production, and climate. In drylands, cover crops can build up soil organic 483 matter by protecting soil from water and wind erosion and by incorporating extra plant residues 
484 into the soil. However, cover crops may depress main crop yields in water-limited regions by 485 reducing water availability (Blanco-Canqui et al., 2015), which may counterbalance to some 486 extent the organic matter inputs. Nonetheless, a number of studies in drylands indicate that 487 reducing or eliminating the fallow period by using cover crops, especially if combined with 488 practices that enhance water storage such as no tillage, can significantly increase plant-derived 489 organic matter inputs and slow erosion and decomposition rates, resulting in net gains in soil 490 organic matter stocks (Blanco-Canqui et al., 2013; Paustian, 2014; Mitchell et al., 2017).

Conservation tillage. In contrast to intensive tillage, conservation practices that entail little or 492 no soil disturbance can maintain and even build up surface soil organic matter by slowing 493 macroaggregate turnover, encouraging microaggregate formation, physically protecting crop494 derived particulate organic matter (Paustian et al., 2000; West and Post, 2002; Six et al., 2000, 495 2004; Plaza et al., 2013), and prompting the formation of primary organo-mineral complexes, 496 particularly with microbial material (Plaza et al., 2013) (Figures 12 and 13). A recent meta497 analysis using 46 peer-reviewed publications and 174 paired observations showed that tilled soils 498 emitted 21\% more $\mathrm{CO}_{2}$ than untilled soils across different climates, crop types, and soil 499 conditions, and the difference increased to $29 \%$ in sandy soils from arid climates with low soil 500 organic $\mathrm{C}$ content and low soil moisture (Abdalla et al., 2016). In semiarid central Spain, 25 501 years of no-tillage, compared to chisel plowing, resulted in $16 \%$ more organic $\mathrm{C}$ in the 502 uppermost $20 \mathrm{~cm}$ of soil, especially because of an enhanced interaction between mineral particles 503 and microbial material that resulted in the formation of highly stable organo-mineral complexes 504 (Plaza et al., 2013). In southern Texas, under subhumid conditions, no-tillage resulted in 64\% 505 greater soil organic matter stocks compared with the average pools resulting from different 506 tillage treatments of increasing intensity after 16 years (Salinas-Garcia et al., 1997). 
Efficient irrigation. Matching irrigation to crop water demands can raise yields, crop residue

508

509

510

511

512

513

514 potential risks, such as soil salinization and contamination (Halliwell et al., 2001; Lado and Ben-

515 Hur, 2009). At three sites in southeastern Spain, irrigation with wastewater for 20 to 40 years

516 was found not to adversely affect soil properties and in fact increased soil organic matter stocks

517 with respect to irrigation with freshwater (Morugan-Coronado et al., 2013). However, some

518 studies have pointed out the risk of greater mineralization of native soil organic matter (positive

519 priming effects) because of the addition of fresh dissolved organic matter (Lado and Ben-Hur, 520 2009).

521

522

523

524

525

526

527

528

529

\section{Concluding remarks}

As a whole, soil organic $\mathrm{C}$ concentrations in drylands are very low compared to those in other ecosystems. At the same time, drylands cover $45 \%$ of the Earth's land surface, and thus the total amount of organic $\mathrm{C}$ stored in drylands becomes a significant component of the global $\mathrm{C}$ cycle. Unfortunately, while other ecosystems traditionally considered as C sinks (e.g., peatlands) have been intensively investigated, estimates of organic $\mathrm{C}$ stocks in dryland soils are still very 
530 poor and need to be improved strongly. This is extremely important in order to understand their

531 vulnerability to climate change, as well as to develop strategies to recover, preserve, or enhance

532 the ecosystem services provided, which are mostly affected by soil organic matter. Moreover,

533 most drylands are located in poor or developing countries and host about one third of the global

534 human population. As a consequence, further $\mathrm{C}$ losses from these soils may have long-term 535 adverse impacts on soil quality and global food security and, in turn, on social unrest and 536 political instability. In conclusion, soil organic matter plays a key role in soil conservation in 537 several countries, and in drylands in particular, where it represents "the link" among global 538 issues, including land degradation, food security, and climate change.

\section{Acknowledgements}

542

This project has received funding from the European Union's Horizon 2020 research and

544 innovation programme under the Marie Skłodowska-Curie grant agreement No 654132, and

545 from the Spanish Ministry of Economy and Competitiveness under the grants AGL2013-48681

546 and AGL2016-75762-R. FTM acknowledges support from the European Research Council (ERC

547 Grant Agreement 647038 [BIODESERT]) and the Spanish Ministry of Economy and 548 Competitiveness (BIOMOD project, CGL2013-44661-R). 
Abdalla, K., Chivenge, P., Ciais, P., Chaplot, V., 2016. No-tillage lessens soil $\mathrm{CO}_{2}$ emissions the most under arid and sandy soil conditions: results from a meta-analysis. Biogeosciences 13, 3619-3633.

Alvarez, C., Alvarez, C.R., Costantini, A., Basanta, M., 2014. Carbon and nitrogen sequestration in soils under different management in the semi-arid Pampa (Argentina). Soil and Tillage Research 142, 25-31.

Archer, S., 1994. Woody plant encroachment into southwestern grasslands and savannas: rates, patterns and proximate causes. In: Vavra, M., Laycock, W., Pieper, R. (Eds.), Ecological Implications of Livestock Herbivory in the West, Society for Range Management, Denver, CO, pp. 13-68.

Bardgett, R.D., 2005. The Biology of Soil. Oxford University Press, Oxford, UK.

Bardgett, R.D., Wardle, D.A., 2003. Herbivore-mediated linkages between aboveground and belowground communities. Ecology 84, 2258-2268.

Barger, N.N., Archer, S.R., Campbell, J.L., Huang, C., Morton, J.A, Knapp, A.K., 2011. Woody plant proliferation in North American drylands: A synthesis of impacts on ecosystem carbon balance. Journal of Geophysical Research Biogeosciences 116, G00K07.

Bastida, F., Kandeler, E., Hernández, T., García, C., 2008. Long-term effect of municipal solid waste amendment on microbial abundance and humus-associated enzyme activities under semiarid conditions. Microbial Ecology 55, 651-661.

Batjes, N.H., 1996. Total carbon and nitrogen in the soils of the world. European Journal of Soil Science 47, 151-163.

Belnap, J., 2013. Biological soil crusts and wind erosion. In: Belnap, J., Lange, O.L. (Eds.), Biological Soil Crusts: Structure, Function, and Management. Springer, Berlin, Germany. 
Belnap, J., Lange, O.L., 2013. Biological Soil Crusts: Structure, Function, and Management. Springer, Berlin, Germany.

Berdugo, M., Kéfi, S., Soliveres, S., Maestre, F.T., 2017. Plant spatial patterns identify alternative ecosystem multifunctionality states in global drylands. Nature Ecology and Evolution 1, 0003.

Berthrong, S.T., Piñeiro, G., Jobbágy, E.G., Jackson, R.B., 2012. Soil C and N changes with afforestation of grasslands across gradients of precipitation and plantation age. Ecological Applications 22, 76-86.

Biedenbender, S.H., McClaren, M.P., Quade, J., Weltz, M.A., 2004. Landscape patterns of vegetation change indicated by soil carbon isotope composition. Geoderma 119, 69-83.

Blanco-Canqui, H., Holman, J.D., Schlegel, A.J., Tatarko, J., Shaver, T.M., 2013. Replacing fallow with cover crops in a semiarid soil: Effects on soil properties. Soil Science Society of America Journal 77, 1026-1034.

Blanco-Canqui, H., Shaver, T.M., Lindquist, J.L., Shapiro, C.A., Elmore, R.W., Francis, C.A., Hergert, G.W., 2015. Cover crops and ecosystem services: insights from studies in temperate soils. Agronomy Journal 107, 2449-2474.

Blanco-Canqui, H., Tatarko, J., Stalker, A.L., Shaver, T.M., Van Donk, S.J., 2016. Impacts of corn residue grazing and baling on wind erosion potential in a semiarid environment. Soil Science Society of America Journal 80, 1027-1037.

Bobbink, R., Hicks, K., Galloway, J., Spranger, T., Alkemade, R., Ashmore, M., Bustamante, M., Cinderby, S., Davidson, E., Dentener, F., Emmet, B., Erisman, J.-W., Fenn, M., Gilliam, F., Nordin, A., Pardo, L., De Vries, W., 2010. Global assessment of nitrogen deposition effects on terrestrial plant diversity: a synthesis. Ecological Applications 20, 30-59. 
Bot, A., Benites, J., 2005. The Importance of Soil Organic Matter. Key to Drought-resistant Soil and Sustained Food and Production. FAO Soils Bulletin 80. FAO, Rome, Italy.

Bowker, M.A., 2007. Biological soil crust rehabilitation in theory and practice: An underexploited opportunity. Restoration Ecology 15, 13-23.

Brazier, R.E., Turnbull, L., Wainwright, J., Bol, R., 2014. Carbon loss by water erosion in drylands: implications from a study of vegetation change in the south-west USA. Hydrological Processes 28, 2212-2222.

Castillo-Monroy, A.P., Maestre, F.T., Rey, A., Soliveres, S., García-Palacios, P., 2011. Biological soil crust microsites are the main contributor to soil respiration in a semiarid ecosystem. Ecosystems 14, 835-847.

Chang, R., Jin, T., Lü, Y., Liu, G., Fu, B., 2014. Soil carbon and nitrogen changes following afforestation of marginal cropland across a precipitation gradient in Loess Plateau of China. PLoS ONE 9, e85426.

Ciais, P., Bombelli, A., Williams, M., Piao, S.L., Chave, J., Ryan, C.M., Henry, M., Brender, P., Valentini, R., 2011. The carbon balance of Africa: synthesis of recent research studies. Philosophical Transactions of the Royal Society A 369, 2038-2057.

Cook, B.I., Ault, T.R., Smerdon, J.E., 2015. Unprecedented 21st century drought risk in the American Southwest and Central Plains. Science Advances 1, e1400082.

Courtier-Murias, D., Simpson, A.J., Marzadori, C., Baldoni, G., Ciavatta, C., Fernández, J.M., López-de-Sá, E.G., Plaza, C., 2013. Unraveling the long-term stabilization mechanisms of organic materials in soils by physical fractionation and NMR spectroscopy. Agriculture, Ecosystems and Environment 171, 9-18.

Dalal, R.C., Chan, K.Y., 2001. Soil organic matter in rainfed cropping systems of the Australian 
cereal belt. Australian Journal of Soil Research 39, 435-464.

623 Darrouzet-Nardi, A., 2013. How much carbon is stored in dryland soils?

624 http://anthony.darrouzet-nardi.net/scienceblog/?p=1664 (accessed 10 October 2016).

625 Daryanto, S., Eldridge, D.J., Throop, H.L., 2013. Managing semi-arid woodlands for carbon 626 storage: grazing and shrub effects on above- and belowground carbon. Agriculture, 627 Ecosystems and Environment 169, 1-11.

628 De Deyn, G.B., Cornelissen, J.H.C., Bardgett, R.D., 2008. Plant functional traits and soil carbon 629 sequestration in contrasting biomes. Ecology letters 11, 516-531.

630

631

632

633

634

635

636

637

638

639

640

641

642

643

644

Delgado-Baquerizo, M., Maestre, F.T., Gallardo, A., Bowker, M.A., Wallenstein, M.D., Quero, J.L., Ochoa, V., Gozalo, B., García-Gómez, M., Soliveres, S., García-Palacios, P., Berdugo, M., Valencia, E., Escolar, C., Arredondo, T., Barraza-Zepeda, C., Bran, D., Carreira, J.A., Chaieb, M., Conceição, A.A., Derak, M., Eldridge, D.J., Escudero, A., Espinosa, C.I., Gaitán, J., Gatica, M.G., Gómez-González, S., Guzman, E., Gutiérrez, J.R., Florentino, A., Hepper, E., Hernández, R.M., Huber-Sannwald, E., Jankju, M., Liu, J., Mau, R.L., Miriti, M., Monerris, J., Naseri, K., Noumi, Z., Polo, V., Prina, A., Pucheta, E., Ramírez, E., Ramírez-Collantes, D.A., Romão, R., Tighe, M., Torres, D., Torres-Díaz, C., Ungar, E.D., Val, J., Wamiti, W., Wang, D., Zaady, E., 2013. Decoupling of soil nutrient cycles as a function of aridity in global drylands. Nature 502, 672-676.

Delgado-Baquerizo, M., Maestre, F.T., Reich, P.B., Jeffries, T.C., Gaitán, J.J., Encinar, D., Berdugo, M., Campbell, C.D., Singh, B.K., 2016. Microbial diversity drives multifunctionality in terrestrial ecosystems. Nature Communications 7, 10541.

Diacono, M., Montemurro, F., 2010. Long-term effects of organic amendments on soil fertility. A review. Agronomy for Sustainable Development 30, 401-422. 
645 Dregne, H.E., 1976. Soils of Arid Regions. Developments in Soil Science 6. Elsevier, 646 Amsterdam, The Netherlands.

647 Elbert, W., Weber, B., Büdel, B., Andreae, M.O., Pöschl, U., 2009. Microbiotic crusts on soil, 648 rock and plants: neglected major players in the global cycles of carbon and nitrogen? 649 Biogeosciences Discussions 6, 6983-7015.

650 Elbert, W., Weber, B., Burrows, S., Steinkamp, J., Büdel, B., Andreae, M.O., Pöschl, U., 2012. 651 Contribution of cryptogamic covers to the global cycles of carbon and nitrogen. Nature 652 Geoscience 5, 459-462.

653 Eldridge, D.J., Leys, J.F., 2003. Exploring some relations between biological soil crusts, soil 654 aggregation and wind erosion. Journal of Arid Environments 53, 453-466.

655 Eldridge, D.J., Bowker, M.A., Maestre, F.T., Reynolds, J.F., Roger, E., Whitford, W.G., 2011. 656 Impacts of shrub encroachment on ecosystem structure and functioning: towards a global 657 synthesis. Ecology Letters 14, 709-722.

658 Eldridge, D.J., Poore, A.G.B., Ruiz-Colmenero, M., Letnic, M., Soliveres, S., 2016. Ecosystem 659 structure, function, and composition in rangelands are negatively affected by livestock 660 grazing. Ecological Applications 26, 1273-1283.

661 FAO, 1993. Land degradation in arid, semi-arid and dry sub-humid areas: rainfed and irrigated 662 lands, rangelands and woodlands. Text for FAO presentation at inter-governmental 663 negotiating committee for the preparation of a convention to combat desertification and 664 drought (INCD). FAO, Rome, Italy.

665 FAO, 2004. Carbon Sequestration in Dryland Soils. World Soil Resources Reports 102. FAO, 666 Rome, Italy.

667 FAO/IIASA/ISRIC/ISSCAS/JRC, 2012. Harmonized World Soil Database (version 1.2). FAO, 
Rome, Italy and IIASA, Laxenburg, Austria.

669

670

671

672

673

674

675

676

677

678

679

680

681

682

683

684

685

686

687

688

689

690

Fernández, J.M., Plaza, C., García-Gil, J.C., Polo, A., 2009. Biochemical properties and barley yield in a semiarid Mediterranean soil amended with two kinds of sewage sludge. Applied Soil Ecology 42, 18-24.

Ferrenberg, S., Reed, S.C., Belnap, J., 2015. Climate change and physical disturbance cause similar community shifts in biological soil crusts. Proceedings of the National Academy of Sciences of the United States of America 112, 12116-12121.

Fog, K., 1988. The effect of added nitrogen on the rate of decomposition of organic matter. Biological Reviews of the Cambridge Philosophical Society 63, 433-462.

Foley, J.A., Ramankutty, N., Brauman, K.A., Cassidy, E.S., Gerber, J.S., Johnston, M., Mueller, N.D., O’Connell, C., Ray, D.K., West, P.C., Balzer, C., Bennett, E.M., Carpenter, S.R., Hill, J., Monfreda, C., Polasky, S., Rockström, J., Sheehan, J., Siebert, S., Tilman, D., Zaks, D.P.M., 2011. Nature 478, 337-342.

Fu, Q., Feng, S., 2014. Responses of terrestrial aridity to global warming. Journal of Geophysical Research Atmospheres 119, 7863-7875.

Gaitán, J.J., Bran, D.E., Oliva, G.E., Aguiar, M.R., Buono, G.G., Ferrante, D., Nakamatsu, V., Ciari, G., Salomone, J.M., Massara, V., García Martínez, G., Maestre, F.T., 2017. Aridity and overgrazing have convergent effects on ecosystem structure and functioning in Patagonian rangelands. Land Degradation and Development, doi: 10.1002/1dr.2694.

Gelaw, A.M., Singh, B.R., Lal, R., 2014. Soil organic carbon and total nitrogen stocks under different land uses in a semi-arid watershed in Tigray, Northern Ethiopia. Agriculture, Ecosystems and Environment 188, 256-263.

Golchin, A., Oades, J.M., Skjemstad, J.O., Clarke, P., 1994. Soil structure and carbon cycling. 
Australian Journal of Soil Research 32, 1043-1068.

692 Gruber, N., Galloway, J.N., 2008. An Earth-system perspective of the global nitrogen cycle. $693 \quad$ Nature 451, 293-296.

694 Guo, L.B., Gifford, R.M., 2002. Soil carbon stocks and land use change: a meta analysis. Global 695 Change Biology 8, 345-360.

696 Hai, L., Li, X.G., Li, F.M., Suo, D.R., Guggenberger, G., 2010. Long-term fertilization and 697 698 699 700 701 702

Halliwell, D.J., Barlow, K.M., Nash, D.M., 2001. A review of the effects of wastewater sodium on soil physical properties and their implications for irrigation systems. Australian Journal of Soil Research 39 1259-1267.

Haygarth, P., Ritz, K., 2009. The future of soils and land use in the UK: Soil systems for the provision of land-based ecosystem services. Land Use Policy 26, S187-S197.

Haynes, R.J., Williams, P.H., 1999. The influence of stock camping behaviors on the soil microbial and biochemical properties of grazed pastoral soils. Biology and Fertility of Soils $28,253-258$.

Huang, J., Yu, H., Guan, X., Wang, G., Guo, R., 2016. Accelerated dryland expansion under climate change. Nature Climate Change 6, 166-171.

Hugelius, G., Strauss, J., Zubrzycki, S., Harden, J.W., Schuur, E.A.G., Ping, C.L., Schirrmeister, L., Grosse, G., Michaelson, G.J., Koven, C.D., O’Donnell, J.A., Elberling, B., Mishra, U., Camill, P., Yu, Z., Palmtag, J., Kuhry, P., 2014. Estimated stocks of circumpolar permafrost carbon with quantified uncertainty ranges and identified data gaps. Biogeosciences 11, 6573- 
6593.

715

716

717

718

719

720

721

722

723

724

725

726

727

728

729

730

731

732

733

734

735

736

IIASA/FAO, 2012. Global Agro-ecological Zones (GAEZ v3.0). IIASA, Laxenburg, Austria and FAO, Rome, Italy.

IPCC, 2013. Climate Change 2013: The Physical Science Basis. Contribution of Working Group I to the Fifth Assessment Report of the Intergovernmental Panel on Climate Change [Stocker, T.F., Qin, D., Plattner, G.-K., Tignor, M., Allen, S.K., Boschung, J., Nauels, A., Xia, Y., Bex, V., Midgley, P.M. (Eds.)]. Cambridge University Press, Cambridge, UK.

Jackson, R.B., Banner, J.L., Jobbágy, E.G., Pockman, W.T., Wall, D.H., 2002. Ecosystem carbon loss with woody plant invasion of grasslands. Nature 418, 623-626.

Jenny, H., 1941. Factors of Soil Formation. McGraw-Hill, New York, NY.

Jobbágy, E.G., Jackson, R.B., 2000. The vertical distribution of soil organic carbon and its relation to climate and vegetation. Ecological Applications 10, 423-436.

Johnson, D.W., Curtis, P.S., 2001. Effects of forest management on soil C and N storage: meta analysis. Forest Ecology and Management 140, 227-238.

Kleber, M., Eusterhues, K., Keiluweit, M., Mikutta, C., Mikutta, R., Nico, P.S., 2015. MineralOrganic Associations: Formation, Properties, and Relevance in Soil Environments. Advances in Agronomy 130, 1-140.

Köchy, M., Hiederer, R., Freibauer, A., 2015. Global distribution of soil organic carbon - Part 1: Masses and frequency distributions of SOC stocks for the tropics, permafrost regions, wetlands, and the world. Soil 1, 351-365.

Kotzé, E., Sandhage-Hofmann, A., Meinel, J.-A., du Preeza, C.C., Amelung, W., 2013. Rangeland management impacts on the properties of clayey soils along grazing gradients in the semi-arid grassland biome of South Africa. Journal of Arid Environments 97, 220-229. 
737 Lado, M., Ben-Hur, M., 2009. Treated domestic sewage irrigation effects on soil hydraulic 738 properties in arid and semiarid zones: a review. Soil and Tillage research 106, 152-163.

739 Laganière, J, Angers, D.A., Paré, D., 2010. Carbon accumulation in agricultural soils after 740 afforestation: a meta-analysis. Global Change Biology 16, 439-453.

741 Lal, R., 2001a. Carbon sequestration in dryland ecosystems of West Asia and North Africa. Land 742 Degradation and Development 13, 45-59.

743 Lal, R., 2001b. Potential of desertification control to sequester carbon and mitigate the 744 greenhouse effect. Climatic Change 51, 35-72.

745 Lal, R., 2004a. Carbon sequestration in dryland ecosystems. Environmental Management 33, $746 \quad 528-544$.

747 Lal, R. 2004b. Soil carbon sequestration to mitigate climate change. Geoderma123, 1-22.

748 Lal, R., 2004c. Soil carbon sequestration impacts on global climate change and food security. $749 \quad$ Science 304, 1623-1627.

750 Lal, R., 2009. Challenges and opportunities in soil organic matter research. European Journal of $751 \quad$ Soil Science 60, 158-169.

752 Lan, Z., Bai, Y., 2012. Testing mechanisms of N-enrichment induced species loss in a semiarid 753 inner Mongolia grassland: Critical thresholds and implications for long-term ecosystem 754 responses. Philosophical Transactions of the Royal Society B: Biological Sciences 367, $755 \quad 3125-3134$.

756 Lehmann, J., 2007. A handful of carbon. Nature 447, 143-144.

757 Lehmann, C.E.R., Anderson, T.M., Sankaran, M., Higgins, S.I., Archibald, S., Hoffmann, W.A., 758 Hanan, N.P., Williams, R.J., Fensham, R.J., Felfili, J., Hutley, L.B., Ratnam, J., San Jose, J., 759 Montes, R., Franklin, D., Russell-Smith, J., Ryan, C.M., Durigan, G., Hiernaux, P., Haidar, 
R., Bowman, D.M.J.S., Bond, W.J., 2014. Savanna vegetation-fire-climate relationships differ among continents. Science 343, 548-552.

762 Lehmann, J., Joseph, S., 2015. Biochar for Environmental Management: Science and 763 Technology, 2nd Edition. Earthscan, London, UK.

764 Lehmann, J., Kleber, M., 2015. The contentious nature of soil organic matter. Nature 528, 60-68.

765 Li, D., Niu, S., Luo, Y., 2012. Global patterns of the dynamics of soil carbon and nitrogen stocks 766 following afforestation: a meta-analysis. New Phytologist 195, 172-181.

767 Lloyd, J., 1999. The $\mathrm{CO}_{2}$ dependence of photosynthesis, plant growth responses to elevated CO2 768 concentrations and their interactions with soil nutrient status. II. Temperature and boreal 769 770 771 3847.

Maestre, F.T., Delgado-Baquerizo, M., Jeffries, T.C., Ochoa, V., Gozalo, B., Quero, J.L., GarcíaGómez, M., Gallardo, A., Ulrich, W., Bowker, M.A., Arredondo, T., Barraza-Zepeda, C., 
Bran, D., Florentino, A., Gaitán, J., Gutiérrez, J.R., Huber-Sannwald, E., Jankju, M., Mau, R.L., Miriti, M., Naseri, K., Ospina, A., Stavi, I., Wang, D., Woods, N.N., Yuan, X., Zaady, E., Singh, B.K., 2015. Increasing aridity reduces soil microbial diversity and abundance in global drylands. Proceedings of the National Academy of Sciences of the United States of America 112, 15684-15689.

788

789

790

791

792

793

794

795

796

797

798

799

800

801

802

803

804

805
Maestre, F.T., Eldridge, D.J., Soliveres, S., Kéfi, S., Delgado-Baquerizo, M., Bowker, M.A., Gaitán, J., Berdugo, M., Gallardo, A., Lázaro, R., García-Palacios, P., 2016. Structure and functioning of dryland ecosystems in a changing world. Annual Review of Ecology, Evolution and Systematics 47, 215-237.

Martínez-Mena, M., Álvarez Rogel, J., Castillo V., Albaladejo, J., 2002. Organic carbon and nitrogen influenced by vegetation removal in a semiarid Mediterranean soil. Biogeochemistry 61, 309-321.

Matson, P.A., Parton, W.J., Power, A.G., Swift, M.J., 1997. Agricultural intensification and ecosystem properties. Science 277, 504-509.

McLeod, M.K., Schwenke, G.D., Cowie, A.L., Harden, S., 2013. Soil carbon is only higher in the surface soil under minimum tillage in Vertosols and Chromosols of New South Wales North-West Slopes and Plains, Australia. Soil Research 51, 680-694.

Middleton, N., Stringer, L., Goudie, A., Thomas, D., 2011. The Forgotten Billion. MDG Achievement in the Drylands. UNDP, UNCCD, New York, NY.

Middleton, N.J., Sternberg, T., 2013. Climate hazards in drylands: A review. Earth-Science Reviews 126, 48-57.

Mitchell, J.P., Shrestha, A., Mathesius, K., Scow, K.M., Southard, R.J., Haney, R.L., Schmidt, R., Munk, D.S., Horwath, W.R., 2017. Cover cropping and no-tillage improve soil health in 
an arid irrigated cropping system in California's San Joaquin Valley, USA. Soil and Tillage Research 165, 325-335.

808

809

810

812

813

814

815

816

817

818

819

820

821

822

823

824

825

826

827

828

Morgan, R.P.C., 2005. Soil Erosion and Conservation, $3^{\text {rd }}$ Ed. Blackwell Science, Malden, MA.

Morugan-Coronado, A., Arcenegui, V., García-Orenes, F., Mataix-Solera, J., Mataix-Beneyto, J., 2013. Application of soil quality indices to assess the status of agricultural soils irrigated with treated wastewaters. Solid Earth 4, 119-127.

Naab, J.B., Mahama, G.Y., Koo, J., Jones, J.W., Boote, K.J., 2015. Nitrogen and phosphorus fertilization with crop residue retention enhances crop productivity, soil organic carbon, and total soil nitrogen concentrations in sandy-loam soils in Ghana. Nutrient Cycling in Agroecosystems 102, 33-43.

Nicholson, S.E., 2011. Dryland Climatology. Cambridge University Press, Cambridge, UK.

Ochoa-Hueso, R., Allen, E.B., Branquinho, C., Cruz, C., Dias, T., Fenn, M.E., Manrique, E., Pérez-Corona, M.E., Sheppard, L.J., Stock, W.D., 2011. Nitrogen deposition effects on Mediterranean-type ecosystems: an ecological assessment. Environmental Pollution 159, $2265-2279$.

Ochoa-Hueso, R., Delgado-Baquerizo, M., Gallardo, A., Bowker, M.A., Maestre, F.T., 2016. Climatic conditions, soil fertility and atmospheric nitrogen deposition largely determine the structure and functioning of microbial communities in biocrust-dominated Mediterranean drylands. Plant and Soil 399, 271-282.

Ochoa-Hueso, R., Maestre, F.T., de los Ríos, A., Valea, S., Theobald, M.R., Vivanco, M.G., Manrique, E., Bowker, M.A., 2013. Nitrogen deposition alters nitrogen cycling and reduces soil carbon content in low-productivity semiarid Mediterranean ecosystems. Environmental Pollution 179, 185-193. 
829

830

831

832

833

834

835

836

837

838

839

840

841

842

843

844

845

846

847

848

849

850

851

Ogle, S.M., Breidt, F.J., Paustian, K., 2005. Agricultural management impacts on soil organic carbon storage under moist and dry climatic conditions of temperate and tropical regions. Biogeochemistry 72, 87-121.

Palm, C., Blanco-Canqui, H., DeClerck, F., Gatere, L., Grace, P., 2014. Conservation agriculture and ecosystem services: an overview. Agriculture, Ecosystems and Environment 187, 87105.

Paul, E.A., 2016. The nature and dynamics of soil organic matter: plant inputs, microbial transformations, and organic matter stabilization. Soil Biology and Biochemistry 98, 109126.

Paul, E.A., Paustian, K.H., Elliott, E.T., Cole, C.V., 1997. Soil Organic Matter in Temperate Agroecosystems- Long-term Experiments in North America. CRC Press, Boca Raton, FL.

Paustian, K., Six, J., Elliott, E.T., Hunt, H.W., 2000. Management options for reducing $\mathrm{CO}_{2}$ emissions from agricultural soils. Biogeochemistry 48, 147-163.

Paustian, K. 2014. Soil: carbon sequestration in agricultural systems. In: Van Alfen, N. (Ed.), Encyclopedia of Agriculture and Food Systems. Academic Press, London, UK, p. 140-152.

Piñeiro, G., Paruelo, J.M., Oesterheld, M., Jobbágy, E.G., 2010. Pathways of grazing effects on soil organic carbon and nitrogen. Rangeland Ecology \& Management 63, 109-119.

Plaza, C., Fernández, J.M., Pereira, E.I.P., Polo, A., 2012. A comprehensive method for fractionating soil organic matter into pools not protected and protected from decomposition by physical and chemical mechanisms. CLEAN-Soil Air Water 40, 134-139.

Plaza, C., Courtier-Murias, D., Fernández, J.M., Polo, A., Simpson, A.J., 2013. Physical, chemical, and biochemical mechanisms of soil organic matter stabilization under conservation tillage systems: A central role for microbes and microbial by-products in $\mathrm{C}$ 
sequestration. Soil Biology \& Biochemistry 57, 124-134.

853 Plaza, C., Giannetta, B., Fernández, J.M., López-de-Sá, E.G., Polo, A., Gascó, G., Méndez, A., 854 Zaccone, C., 2016. Response of different soil organic matter pools to biochar and organic 855 fertilizers. Agriculture, Ecosystems \& Environment 225, 150-159.

856 Post, W.M., Kwon, K.C., 2000. Soil carbon sequestration and land-use change: processes and 857 potential. Global Change Biology 6, 317-327.

858 Prăvălie, R., 2016. Drylands extent and environmental issues. A global approach. Earth-Science $859 \quad$ Reviews 161, 259-278.

860 Preger, A.C., Kösters, R., Du Preez, C.C., Brodowski, S., Amelung, W., 2010. Carbon 861 862 863 sequestration in secondary pasture soils: a chronosequence study in the South African Highveld. European Journal of Soil Science 61, 551-562.

Puttock, A., Dungait, J.A.J., Macleod, C.J.A., Bol, R., Brazier, R.E., 2014. Woody plant encroachment into grasslands leads to accelerated erosion of previously stable organic carbon from dryland soils. Journal of Geophysical Research G: Biogeosciences 119, 23452357.

Reynolds, J.F., Stafford Smith, D.M., Lambin, E.F., Turner II, B.L., Mortimore, M., Batterbury, S.P.J., Downing, T.E., Dowlatabadi, H., Fernández, R.J., Herrick, J.E., Huber-Sannwald, E., Jiang, H., Leemans, R., Lynam, T., Maestre, F.T., Ayarza, M., Walker, B., 2007. Gobal desertification: building a science for dryland development. Science 316, 847-851.

871 Safriel, U., Adeel, Z., Niemeijer, D., Puigdefabregas, J., White, R., Lal, R., Winslow, M., 872 Ziedler, J., Prince, S., Archer, E., King, C., Shapiro, B., Wessels, K., Nielsen, T., Portnov, 873 B., Reshef, I., Thonell, J., Lachman, E., McNab, D., 2005. Dryland systems. In: Hassan, R., 874 Scholes, R., Ash, N. (Eds.), The Millennium Ecosystem Assessment Series, Ecosystems and 

623-662.

877 Salinas-Garcia, J.R., Matocha, J.E., Hons, F.M., 1997. Long-term tillage and nitrogen 878 fertilization effects on soil properties of an Alfisol under dryland corn/cotton production. $879 \quad$ Soil and Tillage Research 42, 79-93.

880 Schmidt, M.W.I., Torn, M.S., Abiven, S., Dittmar, T., Guggenberger, G., Janssens, I.A., Kleber, 881 M., Kogel-Knabner, I., Lehmann, J., Manning, D.A.C., Nannipieri, P., Rasse, D.P., Weiner, 882 S., Trumbore, S.E., 2011. Persistence of soil organic matter as an ecosystem property. $883 \quad$ Nature 478, 49-56.

884 Schulze, E.D., Freibauer, A., 2005. Carbon unlocked from soils. Nature 437, 205-206.

885 Schuur, E.A.G., McGuire, A.D., Schädel, C., Grosse, G., Harden, J.W., Hayes, D.J., Hugelius, 886 G., Koven, C.D., Kuhry, P., Lawrence, D.M., Natali, S.M., Olefeldt, D., Romanovsky, V.E., 887 Schaefer, K., Turetsky, M.R., Treat, C.C., Vonk, J.E., 2015. Climate change and the 888 permafrost carbon feedback. Nature 520, 171-179.

889 Senesi, N., Plaza, C., Brunetti, G., Polo, A., 2007. A comparative survey of recent results on 890 humic-like fractions in organic amendments and effects on native soil humic substances. Soil 891 Biology and Biochemistry 39, 1244-1262.

892 Six, J., Elliott, E.T., Paustian, K., Doran, J.W., 1998. Aggregation and soil organic matter 893 accumulation in cultivated and native grassland soils. Soil Science Society of America $894 \quad$ Journal 62, 1367-1377.

895 Six, J., Elliott, E.T., Paustian, K., 1999. Aggregate and soil organic matter dynamics under 896 conventional and no-tillage systems. Soil Science Society of America Journal 63, 1350897 1358. 
898 Six, J., Elliott, E.T., Paustian, K., 2000. Soil macroaggregate turnover and microaggregate 899 formation: a mechanism for $\mathrm{C}$ sequestration under no-tillage agriculture. Soil Biology and $900 \quad$ Biochemistry 32, 2099-2103.

901 Six, J., Conant, R.T., Paul, E.A., Paustian, K., 2002. Stabilization mechanisms of soil organic 902 matter: implications for C-saturation of soils. Plant and Soil 241, 155-176.

903 Six, J., Ogle, S.M., Breidt, F.J., Conant, R.T., Mosier, A.R., Paustian, K., 2004. The potential to 904 mitigate global warming with no-tillage management is only realized when practiced in the 905 long term. Global Change Biology 10, 155-160.

906 Skujins, J., 1991. Semiarid Lands and Deserts. Soil Resource and Reclamation. Marcel Dekker, $907 \quad$ New York, NY.

908 Sollins, P., Homann, P., Caldwell, B.A., 1996. Stabilization and destabilization of soil organic 909 matter: mechanisms and controls. Geoderma 74, 65-105.

910 Stavi, I., Argaman, E., Zaady, E., 2016. Positive impact of moderate stuble grazing on soil 911 quality and organic carbon pool in dryland wheat agro-pastoral systems. Catena 146, 94-99.

912 Thomas, A.D., 2012. Impact of grazing intensity on seasonal variations in soil organic carbon 913 and soil $\mathrm{CO}_{2}$ efflux in two semiarid grasslands in southern Botswana. Philosophical 914 Transactions of the Royal Society B 367, 3076-3086.

915 Thornton, P.K., 2010. Livestock production: recent trends, future prospects. Philosophical 916 Transactions of the Royal Society B 365, 2853-2867.

917 Tilman, D., Balzer, C., Hill, J., Befort, B.L., 2011. Global food demand and the sustainable 918 intensification of agriculture. Proceedings of the National Academy of Sciences of the $919 \quad$ United States of America 108, 20260-20264.

920 Torn, M.S., Swanston, C.W., Castanha, C., Trumbore, S.E., 2009. Storage and turnover of 
natural organic matter in soil. In: Huang, P.M., Senesi, N. (Eds.), Biophysico-Chemical Processes Involving Natural Nonliving Organic Matter in Environmental Systems. John Wiley \& Sons, Hoboken, NJ.

Torn, M.S., Trumbore, S.E., Chadwick, O.A., Vitousek, P.M., Hendricks, D.M., 1997. Mineral control of soil organic carbon storage and turnover. Nature 389, 170-173.

Trumbore, S., 2009. Radiocarbon and soil carbon dynamics. Annual Review of Earth and Planetary Sciences 37, 47-66.

Turnbull, L., Wainwright, J., Brazier, R.E., 2010. Changes in hydrology and erosion over a transition from grassland to shrubland. Hydrological Processes 24, 393-414.

UN Environmental Management Group, 2011. Global Drylands: A UN System-wide Response. UN.

UNCCD, 1994. United Nations Convention to Combat Desertification in those Countries Experiencing Serious Drought and/or Desertification, Particularly in Africa. A/AC.241/27.

UN-DESA-PD, 2015. World Population Prospects: The 2015 Revision, Data Booklet. ST/ESA/SER.A/377.

UNEP, 1997. World Atlas of Desertification, 2nd ed. Edward Arnold, London, UK.

UNEP-WCMC, 2007. A spatial analysis approach to the global delineation of dryland areas of relevance to the CBD Programme of Work on Dry and Subhumid Lands. Dataset based on spatial analysis between WWF terrestrial ecoregions (WWF-US, 2004) and aridity zones (CRU/UEA; UNEPGRID, 1991). Dataset checked and refined to remove many gaps, overlaps and slivers (July 2014).

Van Auken, O.W., 2000. Shrub invasions of North American semiarid grasslands. Annual Review of Ecology and Systematics 31, 197-215. 
944 Vitousek, P.M., Mooney, H.A., Lubchenco, J., Melillo, J.M., 1997. Human domination of $945 \quad$ Earth's ecosystems. Science 277, 494-499.

946 Von Lützow, M., Kögel-Knabner, I., Ekschmitt, K., Matzner, E., Guggenberger, G., Marschner, 947 B., Flessa, H., 2006. Stabilization of organic matter in temperate soils: mechanisms and their 948 relevance under different soil conditions - a review. European Journal of Soil Science 57, $949 \quad 426-445$.

950 Waldrop, M.P., Zak, D.R., Sinsabaugh, R.L., 2004. Microbial community response to nitrogen 951 deposition in northern forest ecosystems. Soil Biology and Biochemistry 36, 1443-1451.

952 Warren, S.D., Eldridge, D.J., 2003. Biological soil crust and livestock in arid ecosystems: are 953 they compatible? In: Belnap, J., Lange, O.L. (Eds.), Biological Soil Crusts: Structure, 954 Function, and Management. Springer, Berlin, Germany, pp. 401-415.

955 West, T.O., Post, W.M., 2002. Soil organic carbon sequestration rates by tillage and crop 956 rotation: a global data analysis. Soil Science Society America Journal 66, 1930-1946.

957 Yang, R., Su, Y.-Z., Wang, T., Yang, Q., 2016. Effect of chemical and organic fertilization on 958 soil carbon and nitrogen accumulation in a newly cultivated farmland. Journal of Integrative $959 \quad$ Agriculture 15, 658-666.

960 Zak, D.R., Freedman, Z.B., Upchurch, R., Steffens, M., Kögel-Knabner, I., 2016. Anthropogenic $961 \quad \mathrm{~N}$ deposition increases soil organic matter accumulation without altering its biochemical 962 composition. Global Change Biology 23, 933-944.

963 Zhang, F., Li, C., Wang, Z., Glidden, S., Grogan, D.S., Li, X., Cheng, Y., Frolking, S., 2015. 964 Modeling impacts of management on farmland soil carbon dynamics along a climate 965 gradient in Northwest China during 1981-2000. Ecological Modelling 312, 1-10. 


\section{FIGURE CAPTIONS}

Figure 1. Map of dryland areas in accordance with the United Nations Convention to Combat Desertification (UNCCD) and Convention on Biological Diversity (CBD) definitions (UNEPWCMC, 2007). Based on the aridity index (AI), or ratio of total annual precipitation to potential evapotranspiration, drylands are divided into hyperarid (AI less than 0.05), arid (AI within the rage from 0.05 to 0.2 ), semiarid (AI from 0.2 to 0.5 ), and dry subhumid regions (AI from 0.5 to 0.65 ).

Figure 2. Simplified global C cycle and soil C stocks in drylands (data from Safriel et al., 2005; IPCC, 2013).

Figure 3. Organic matter transformation, stabilization, and protection from decomposition in soils (redrawn from Courtier-Murias et al., 2013, with permission from Elsevier).

Figure 4. Soil organic matter $(\mathrm{OM})$ fractions isolated from a dryland soil and their links to conceptual mechanisms of stabilization and protection from decomposition (reprinted from Plaza et al., 2013, with permission from Elsevier).

Figure 5. Typical patchy vegetation of drylands (image by Fernando T. Maestre).

Figure 6. Biological soil crust (image by Fernando T. Maestre).

Figure 7. Total organic $\mathrm{C}$ content of semiarid soils under no tillage, chisel plow, and moldboard plow for 23 years (1986-2009) either unamended or organically amended for 2 years (2007-2009). Within the same tillage system, different lowercase letters indicate significant differences according to the LSD test at the 0.05 level. Within the same amendment system, different uppercase letters indicate significant differences according to the LSD test at the 0.05 level (data from Haller, 2011).

Figure 8. Main strategies to restore, preserve, and enhance soil organic matter in drylands (Lal, 2004a, 2009).

Figure 9. Grain, straw, and total dry matter yield of winter barley (Hordeum vulgare L.) grown on semiarid soils either unamended (C) or amended with mineral fertilizer (MF), 20 and $80 \mathrm{Mg} \mathrm{ha}^{-1}$ of sewage sludge compost (CS20 and CS80), and 20 and $80 \mathrm{Mg} \mathrm{ha}^{-1}$ of thermally dried sewage sludge (TS20 and TS80). Within the same yield component, different letters indicate significant differences based on LSD test at the 0.05 level (data from Fernández et al., 2009).

Figure 10. Carbon biomass cycle and sequestration in biochar. Plants store atmospheric $\mathrm{C}$ by photosynthesis in their biomass. Biomass $\mathrm{C}$ is released back into the atmosphere by plant respiration or incorporated into the soil. Soil organic $\mathrm{C}$ decompose and release $\mathrm{C}$ into the atmosphere. The pyrolysis of biomass generates energy and biochar, with very stable $\mathrm{C}$ structures that decompose very slowly and can be stored in soils for much longer than the biomass $\mathrm{C}$ from which it originates (Lehmann, 2007; Lehmann and Joseph, 2015).

Figure 11. Free, intra-macroaggregate, intra-microaggregate, and mineral-associated organic $\mathrm{C}$ content of soils either unamended (UN), amended with municipal solid waste compost (MC), or amended with sewage sludge (SS), without or with biochar (BC). Error bars indicate pooled 
standard error. Different letters indicate significant differences according to LSD test at the 0.05 level (reprinted from Plaza et al., 2016, with permission from Elsevier).

Figure 12. Organic $\mathrm{C}$ content (on whole soil basis) of no-tillage and chisel tilled semiarid soils and in the corresponding free (FR), intra-macroaggregate (MA), intra-microaggregate (MI), mineral-associated (Min), and dissolved (DOM) organic matter fractions. Mean \pm standard error, $\mathrm{n}=3$ (data from Plaza et al., 2013).

Figure 13. Diffusion edited ${ }^{1} \mathrm{H}$ HR-MAS NMR spectra of microbes cultured from soil, barley straw, semiarid soils under chisel tillage for 25 years, and their respective free, intramacroaggregate, intra-microaggregate, and mineral-associated organic matter (OM) pools. General assignments of chemical shift ranges are as follows: (a) $\mathrm{CH}_{3}$ and $\mathrm{CH}_{2}(0.6-1.3 \mathrm{ppm}$ ); (b) $\mathrm{CH}_{3}$ and $\mathrm{CH}_{2}$ near $\mathrm{O}$ and $\mathrm{N}$ (1.3-2.9 ppm); (c) O-alkyl, mainly from carbohydrates and lignin (2.9$4.1 \mathrm{ppm}$ ); (d) $\alpha-\mathrm{H}$ from peptides (4.1-4.8 ppm); (e) aromatic, from lignin and peptides (6.2-7.8 $\mathrm{ppm}$ ); and (f) amide in peptides (7.8-8.4 ppm). It is noteworthy that the spectrum of the mineralassociated OM pool is very similar to that of soil microbial cultures, whereas the spectra of the other OM fractions more closely resemble that of barley straw (spectra redrawn from Plaza et al., 2013 and Courtier-Murias et al., 2013 with permission from Elsevier). 


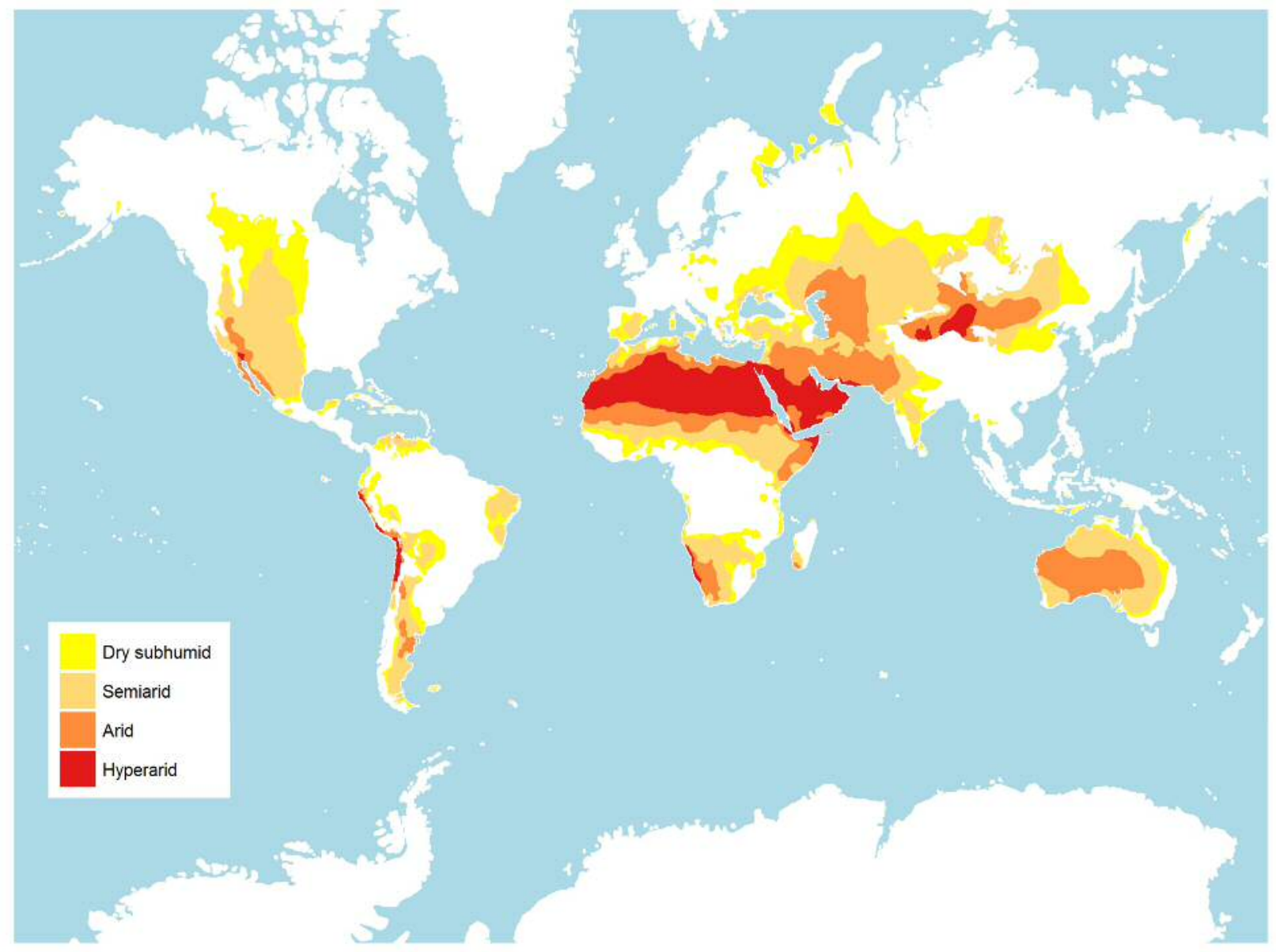

Figure 1. Map of dryland areas in accordance with the United Nations Convention to Combat Desertification (UNCCD) and Convention on Biological Diversity (CBD) definitions (UNEPWCMC, 2007). Based on the aridity index (AI), or ratio of total annual precipitation to potential evapotranspiration, drylands are divided into hyperarid (AI less than 0.05), arid (AI within the rage from 0.05 to 0.2 ), semiarid (AI from 0.2 to 0.5 ), and dry subhumid regions (AI from 0.5 to 0.65 ). 


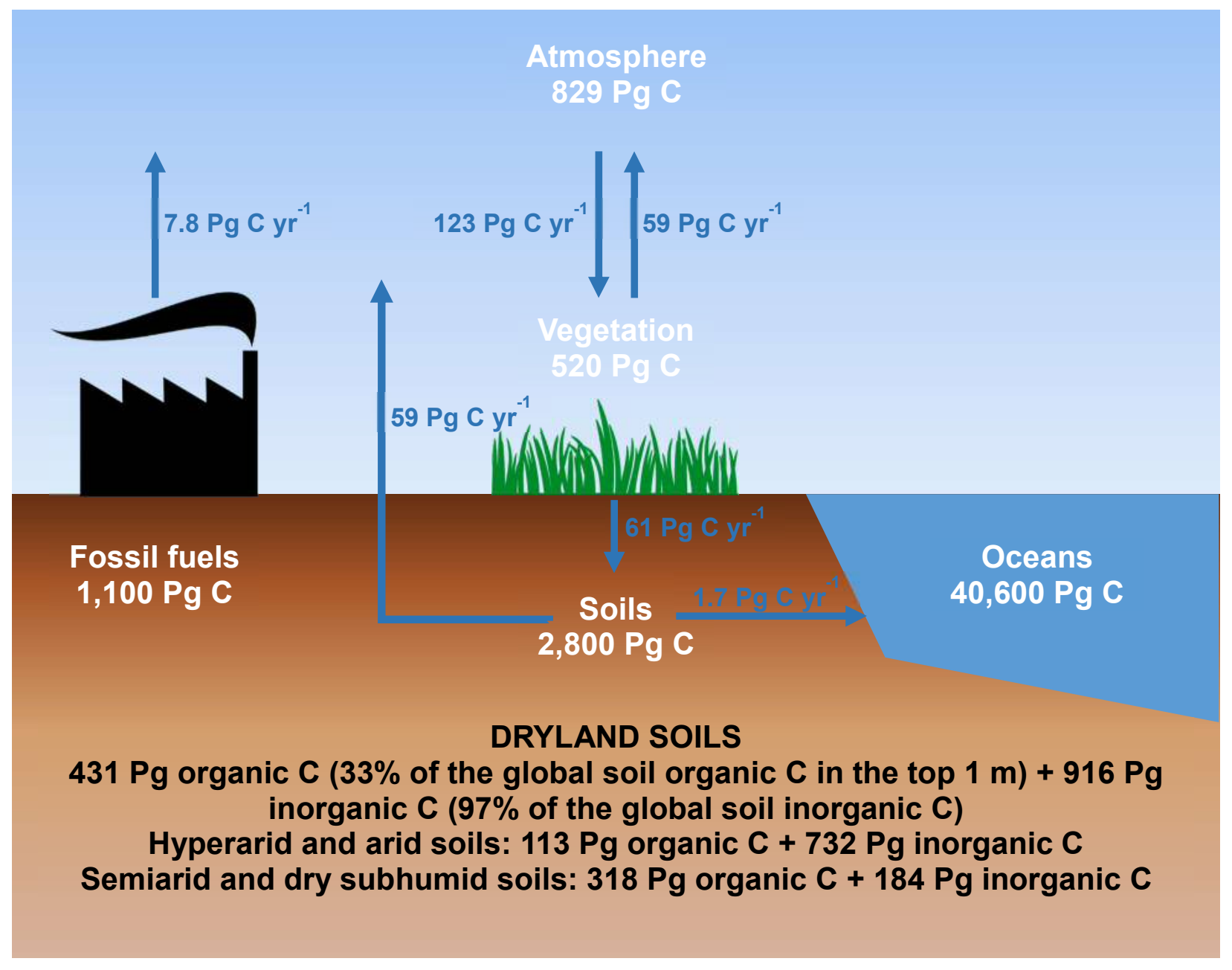

Figure 2. Simplified global C cycle and soil C stocks in drylands (data from Safriel et al., 2005; IPCC, 2013). 


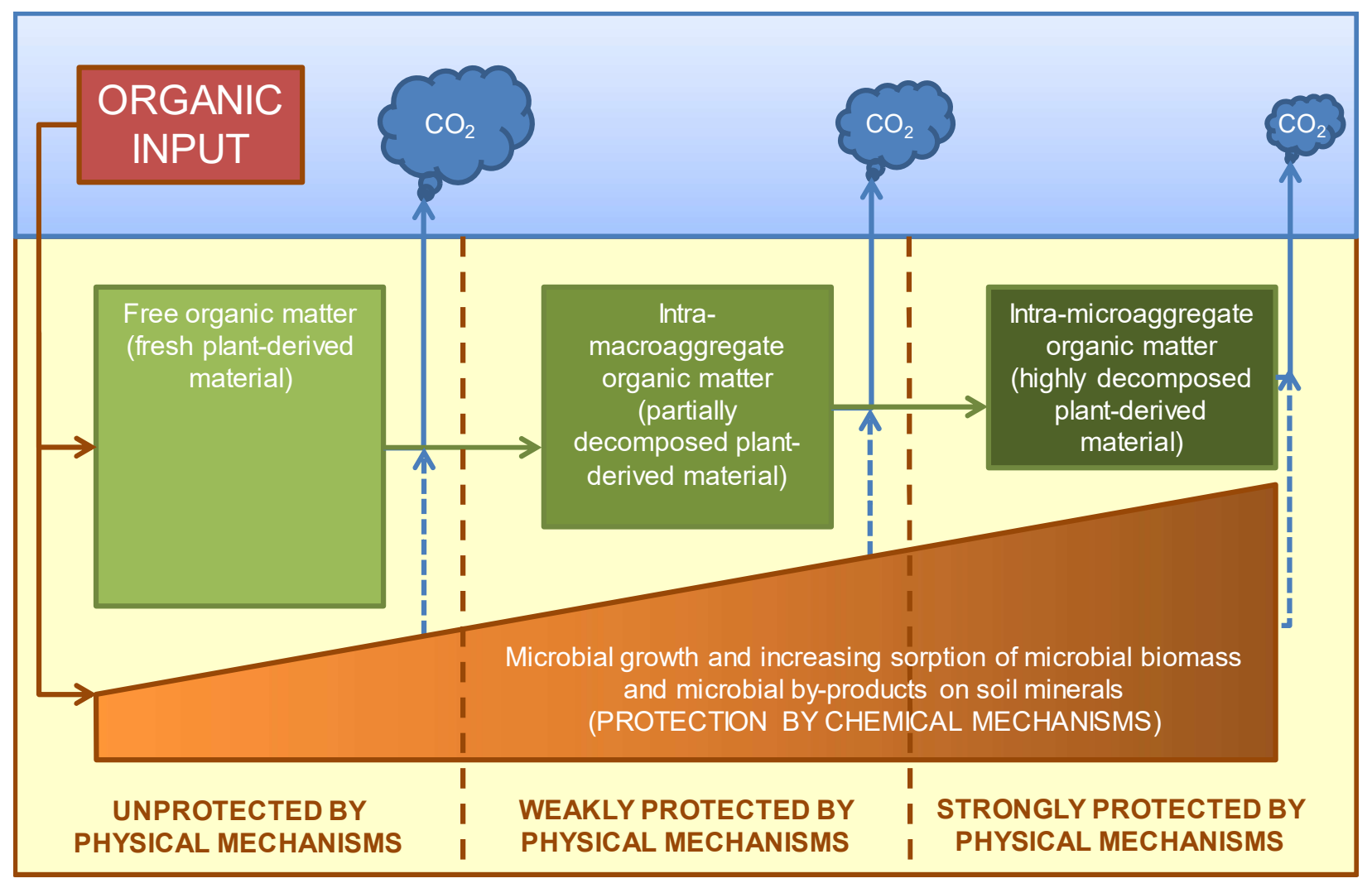

Figure 3. Organic matter transformation, stabilization, and protection from decomposition in soils (redrawn from Courtier-Murias et al., 2013, with permission from Elsevier). 

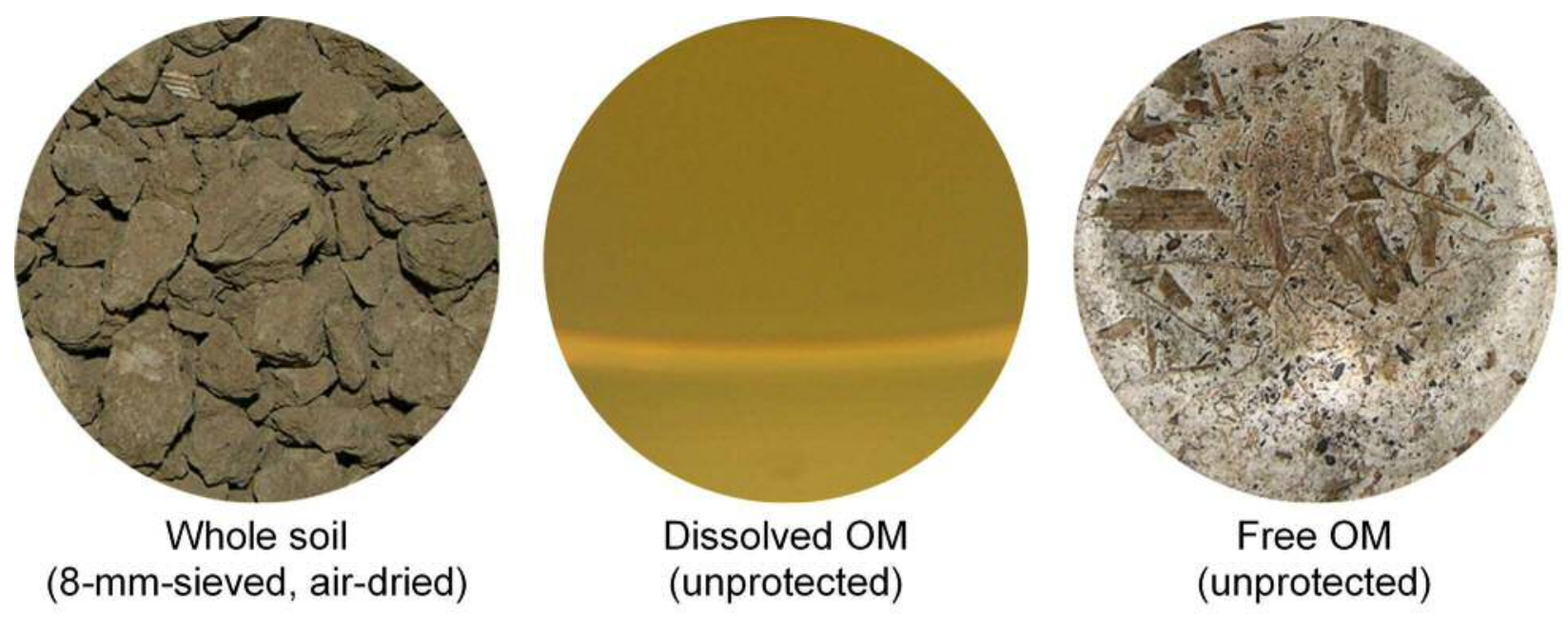

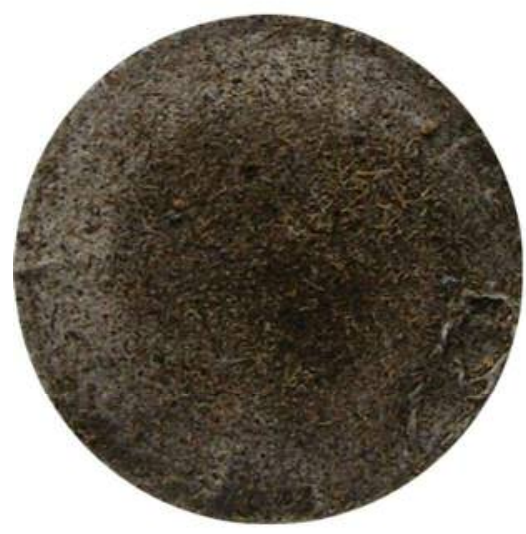

Intra-macroaggregate OM (weakly protected by physical mechanisms)

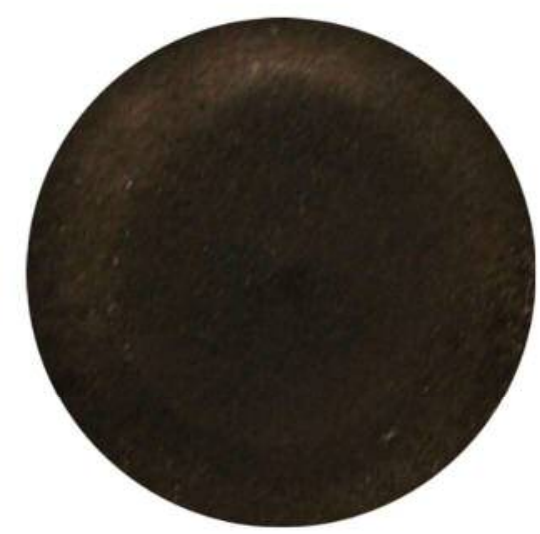

Intra-microaggregate OM (strongly protected by physical mechanisms)

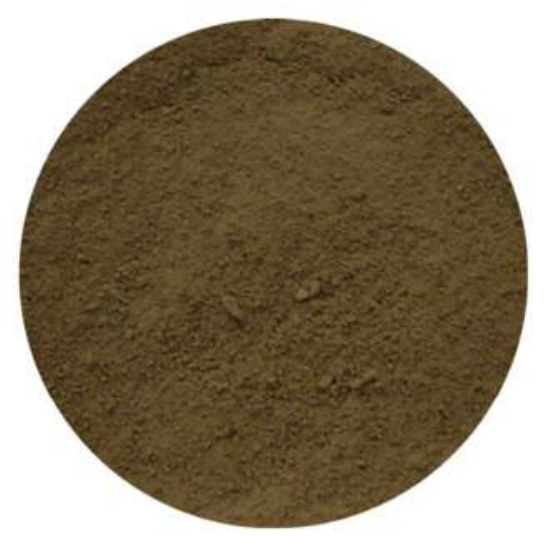

Mineral-associated OM (protected by chemical mechanisms)

Figure 4. Soil organic matter (OM) fractions isolated from a dryland soil and their links to conceptual mechanisms of stabilization and protection from decomposition (reprinted from Plaza et al., 2013, with permission from Elsevier). 


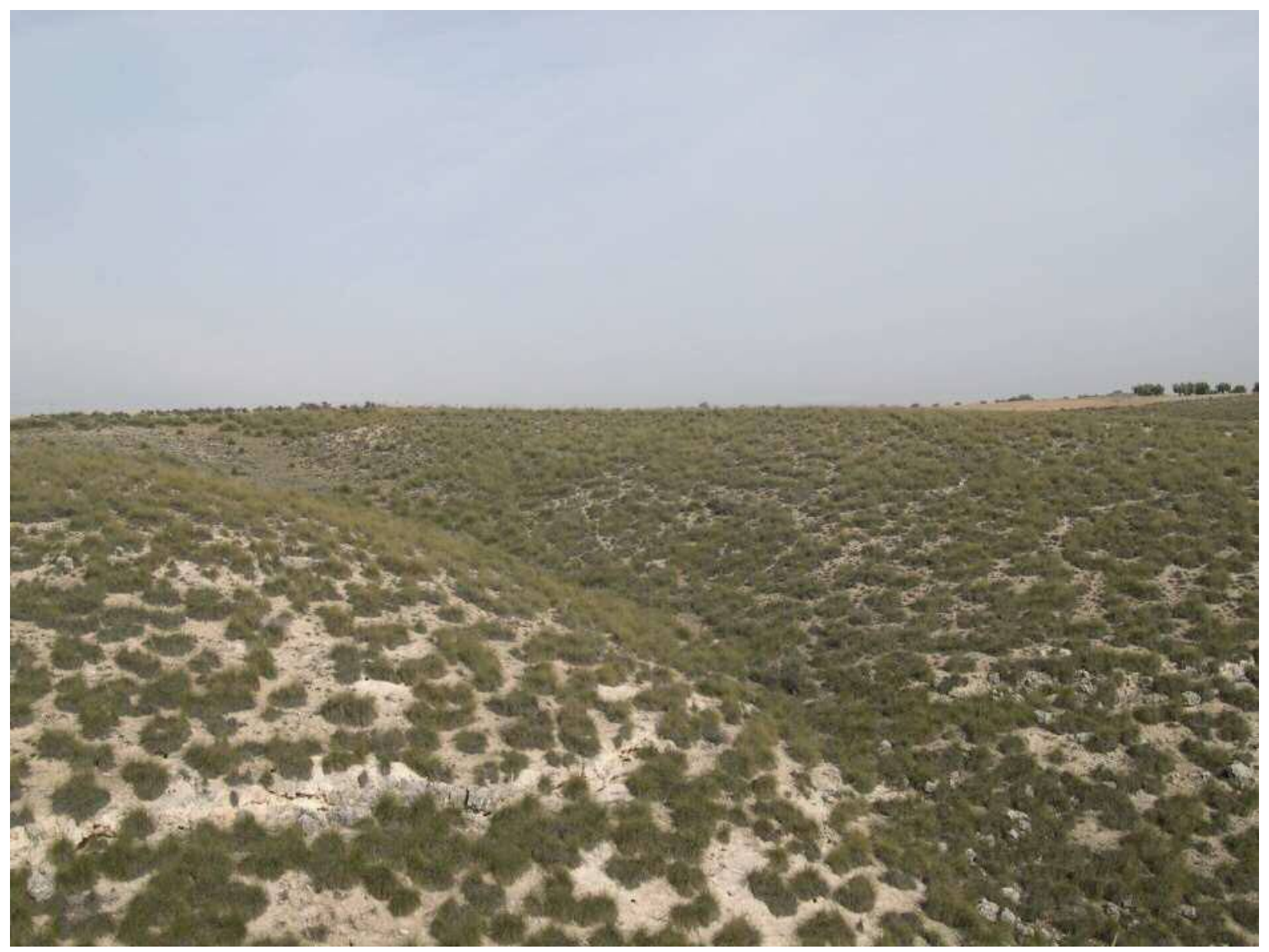

Figure 5. Typical patchy vegetation of drylands (image by Fernando T. Maestre). 


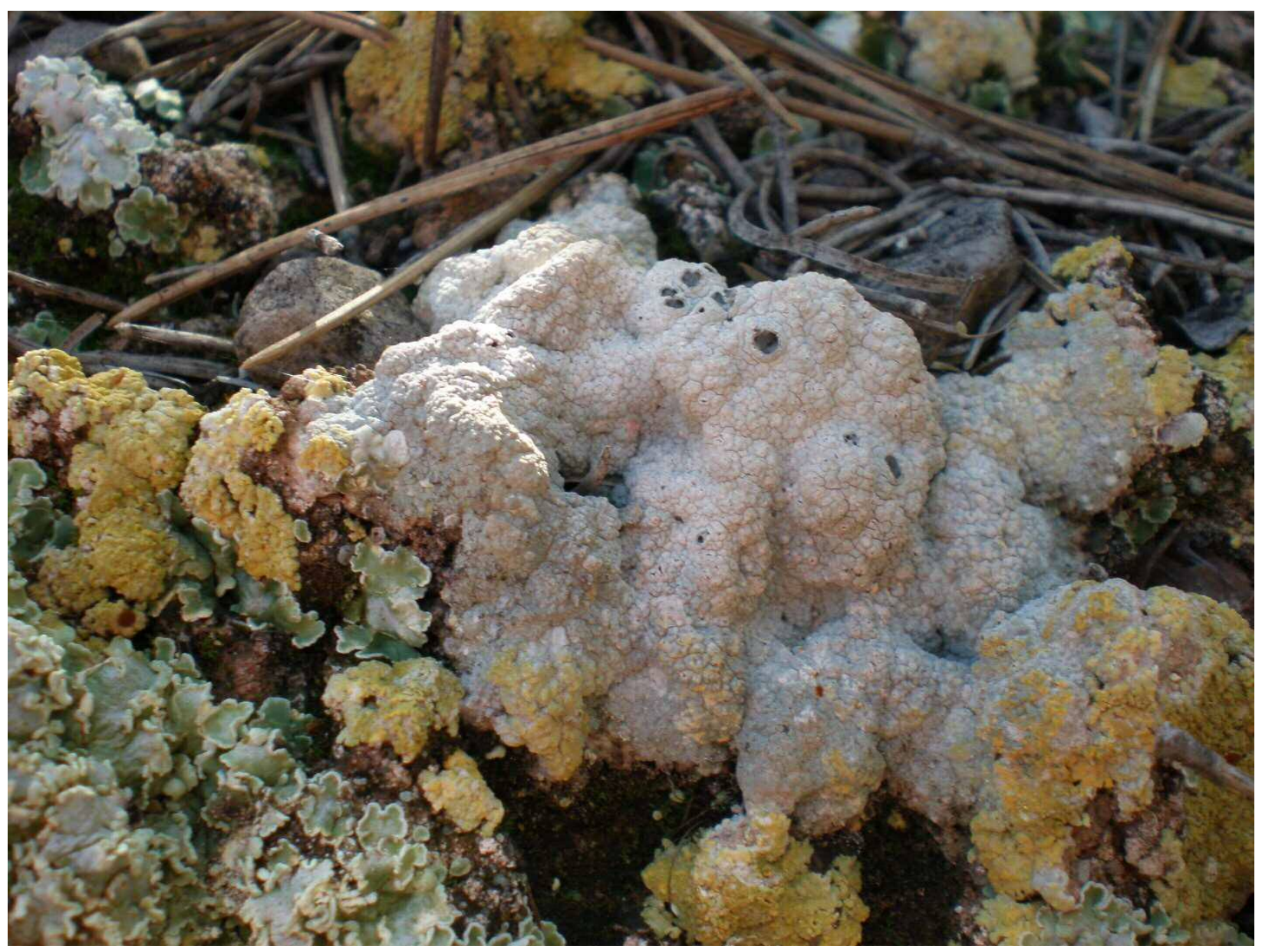

Figure 6. Biological soil crust (image by Fernando T. Maestre). 


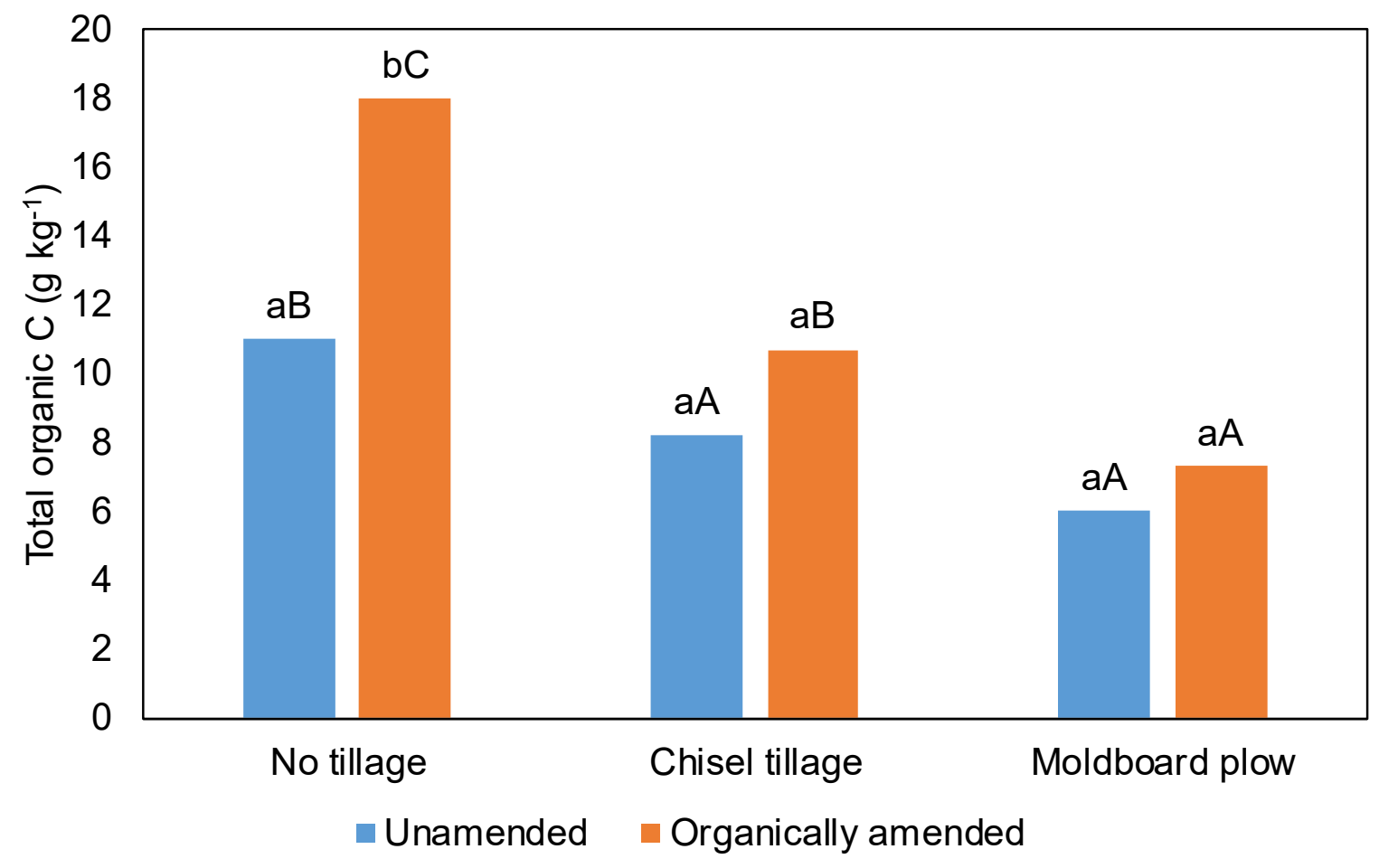

Figure 7. Total organic $\mathrm{C}$ content of semiarid soils under no tillage, chisel plow, and moldboard plow for 23 years (1986-2009) either unamended or organically amended for 2 years (2007-2009). Within the same tillage system, different lowercase letters indicate significant differences according to the LSD test at the 0.05 level. Within the same amendment system, different uppercase letters indicate significant differences according to the LSD test at the 0.05 level (data from I. Haller). 


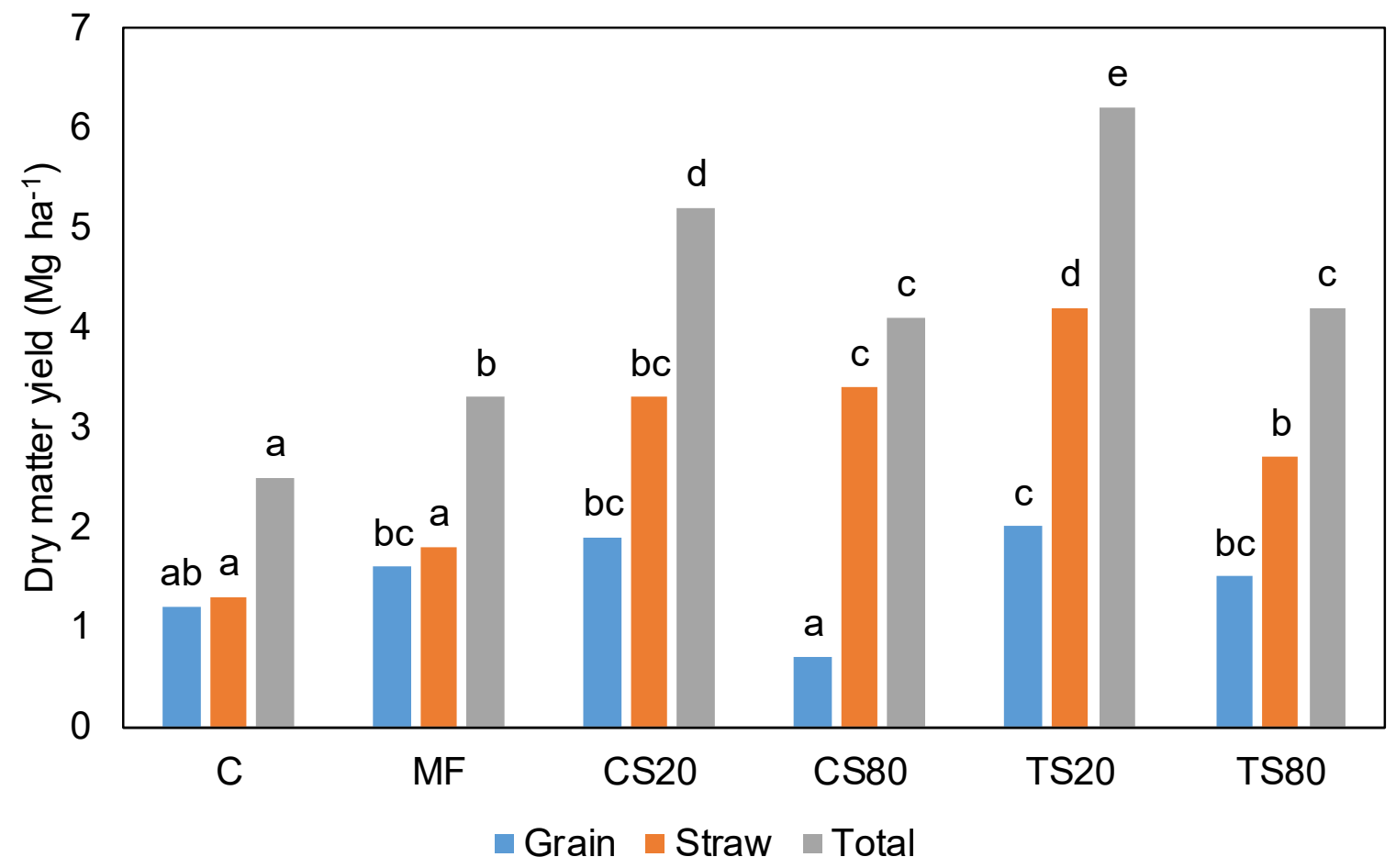

Figure 9. Grain, straw, and total dry matter yield of winter barley (Hordeum vulgare L.) grown on semiarid soils either unamended (C) or amended with mineral fertilizer (MF), 20 and $80 \mathrm{Mg} \mathrm{ha}^{-1}$ of sewage sludge compost (CS20 and CS80), and 20 and $80 \mathrm{Mg} \mathrm{ha}^{-1}$ of thermally dried sewage sludge (TS20 and TS80). Within the same yield component, different letters indicate significant differences based on LSD test at the 0.05 level (data from Fernández et al., 2009). 


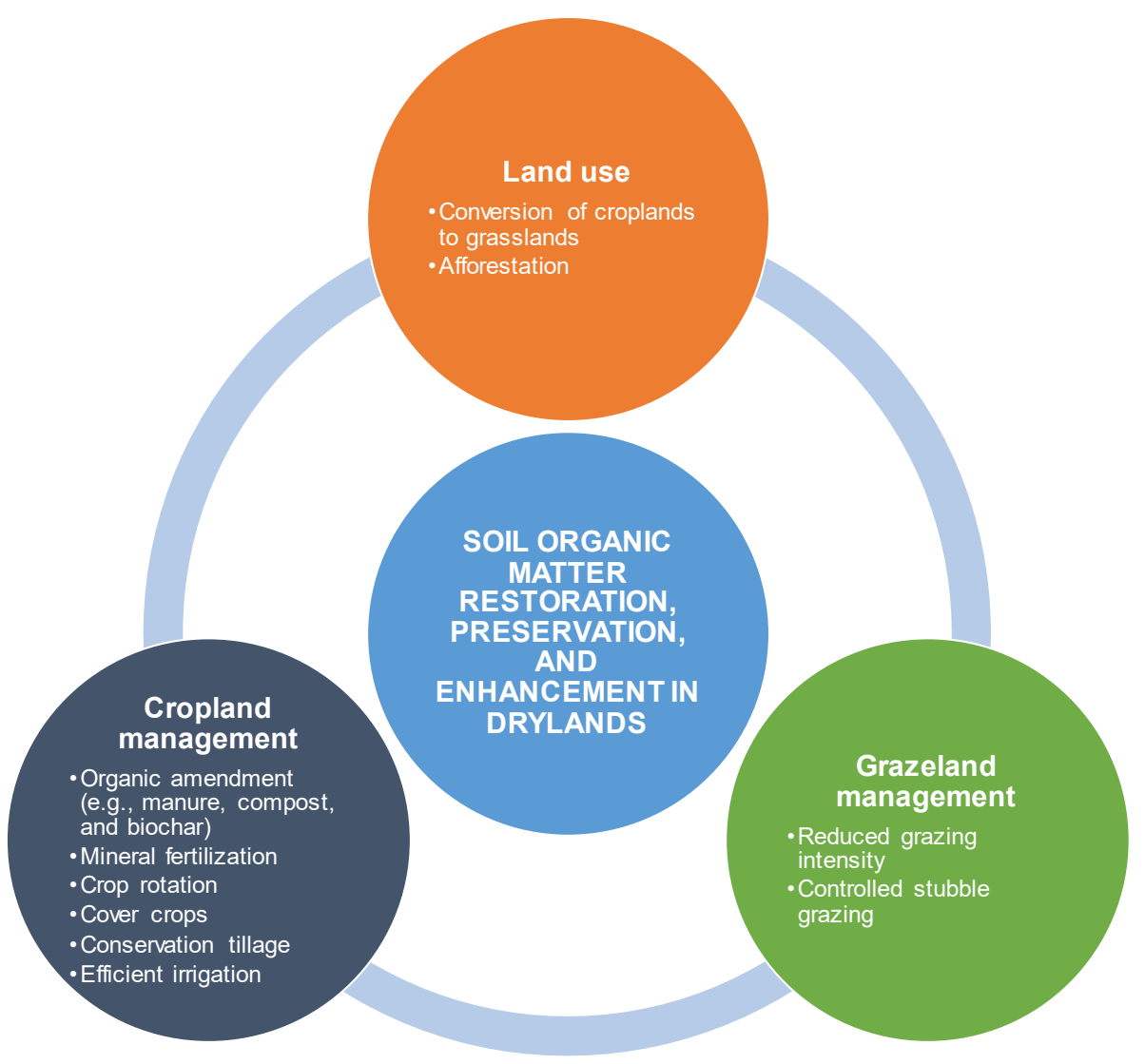

Figure 8. Main strategies to restore, preserve, and enhance soil organic matter in drylands (Lal, 2004a, 2009). 

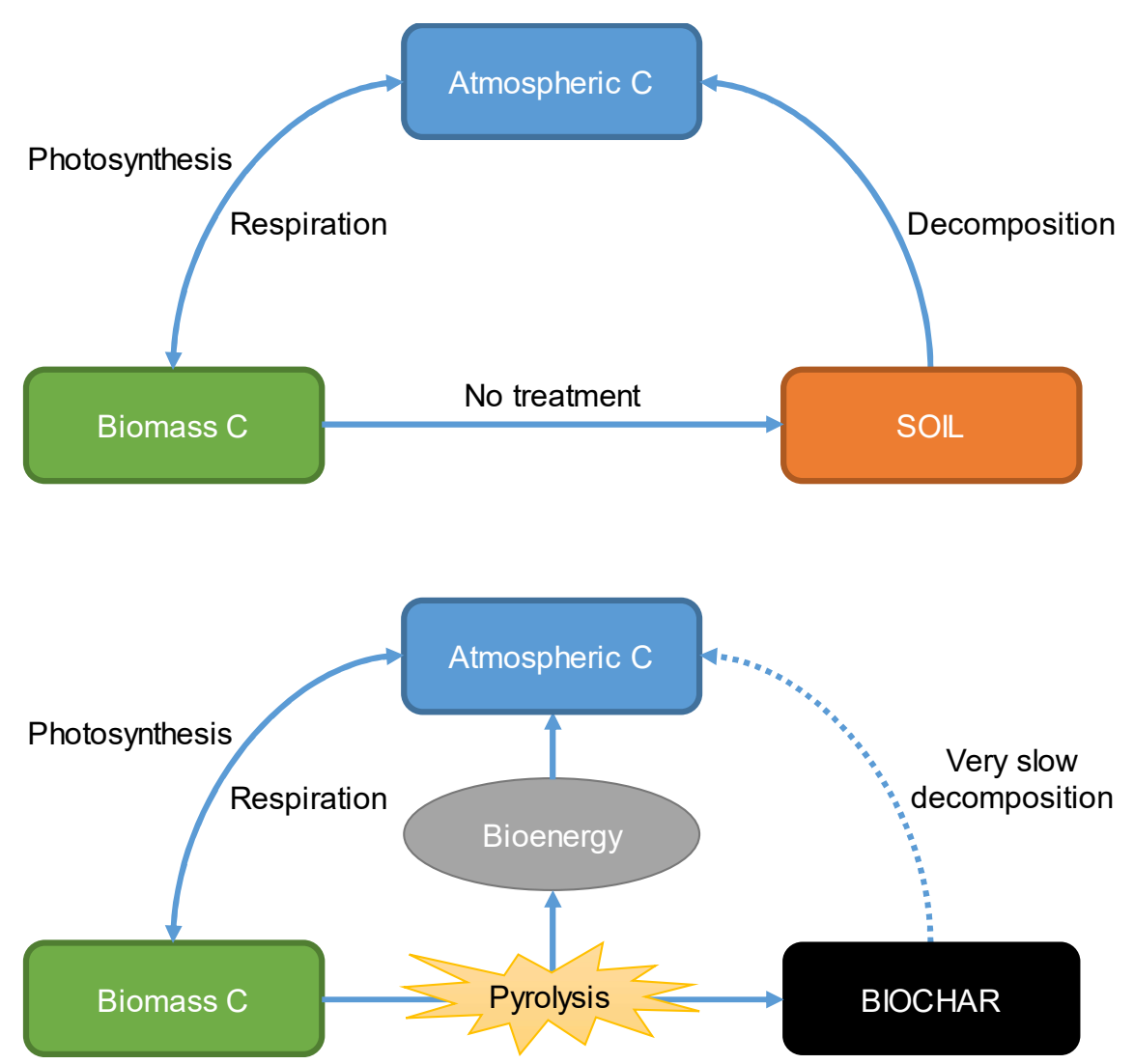

Figure 10. Carbon biomass cycle and sequestration in biochar. Plants store atmospheric $\mathrm{C}$ by photosynthesis in their biomass. Biomass $\mathrm{C}$ is released back into the atmosphere by plant respiration or incorporated into the soil. Soil organic $\mathrm{C}$ decompose and release $\mathrm{C}$ into the atmosphere. The pyrolysis of biomass generates energy and biochar, with very stable $\mathrm{C}$ structures that decompose very slowly and can be stored in soils for much longer than the biomass $\mathrm{C}$ from which it originates (Lehmann, 2007; Lehmann and Joseph, 2015). 

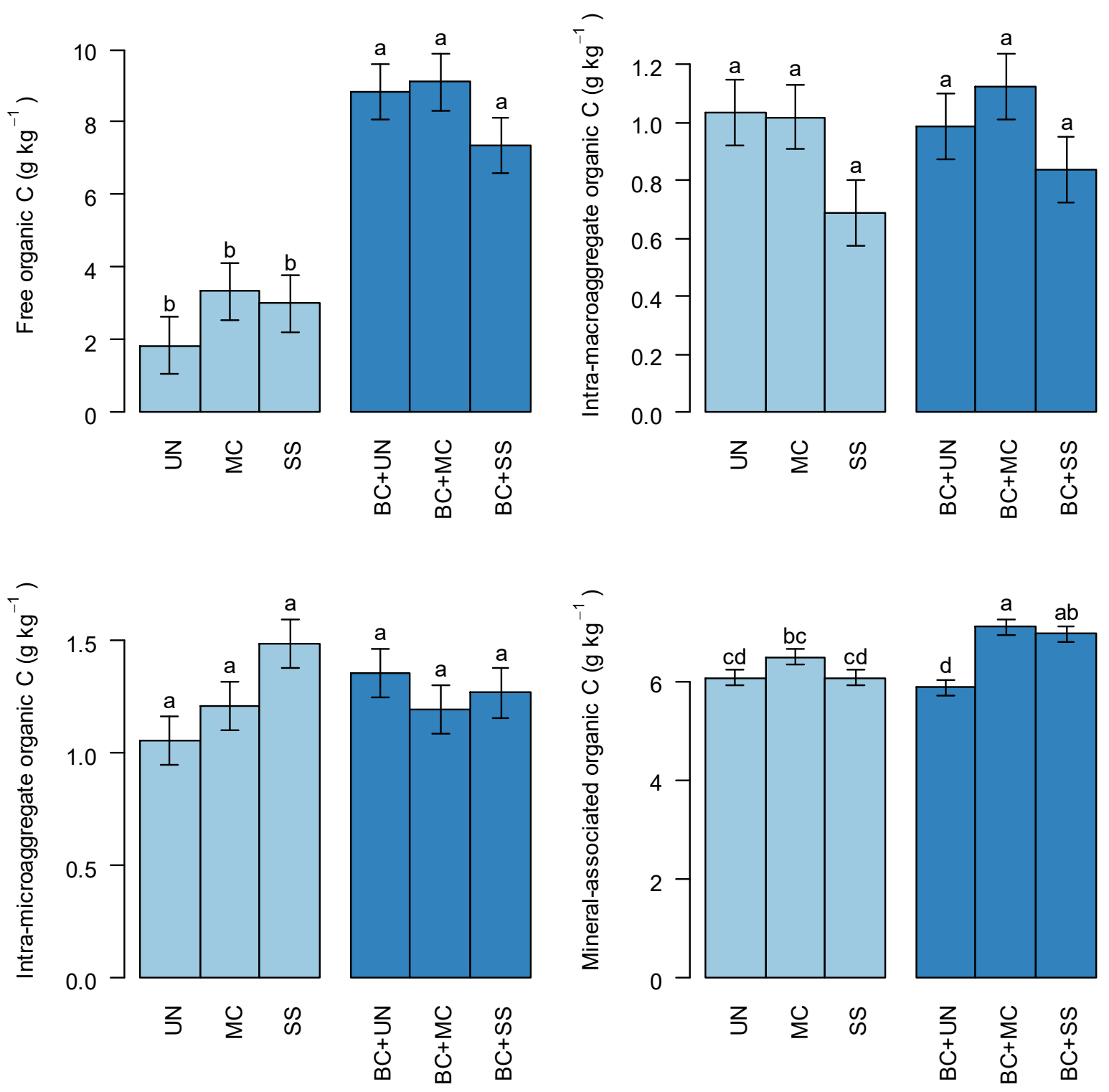

Figure 11. Free, intra-macroaggregate, intra-microaggregate, and mineral-associated organic $\mathrm{C}$ content of soils either unamended (UN), amended with municipal solid waste compost (MC), or amended with sewage sludge (SS), without or with biochar (BC). Error bars indicate pooled standard error. Different letters indicate significant differences according to LSD test at the 0.05 level (reprinted from Plaza et al., 2016, with permission from Elsevier). 


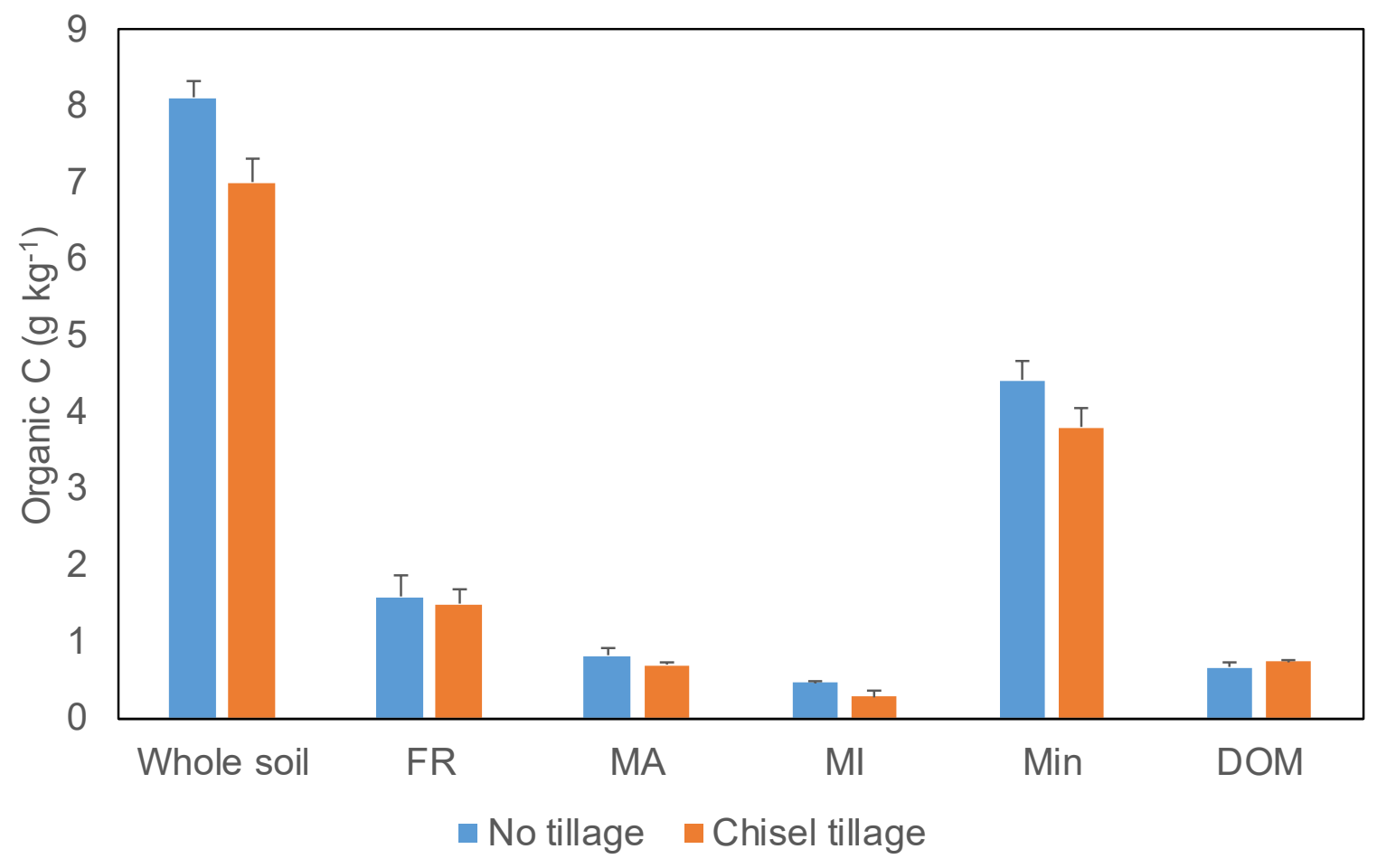

Figure 12. Organic $\mathrm{C}$ content (on whole soil basis) of no-tillage and chisel tilled semiarid soils and in the corresponding free (FR), intra-macroaggregate (MA), intra-microaggregate (MI), mineralassociated (Min), and dissolved (DOM) organic matter fractions. Mean \pm standard error, $n=3$ (data from Plaza et al., 2013). 


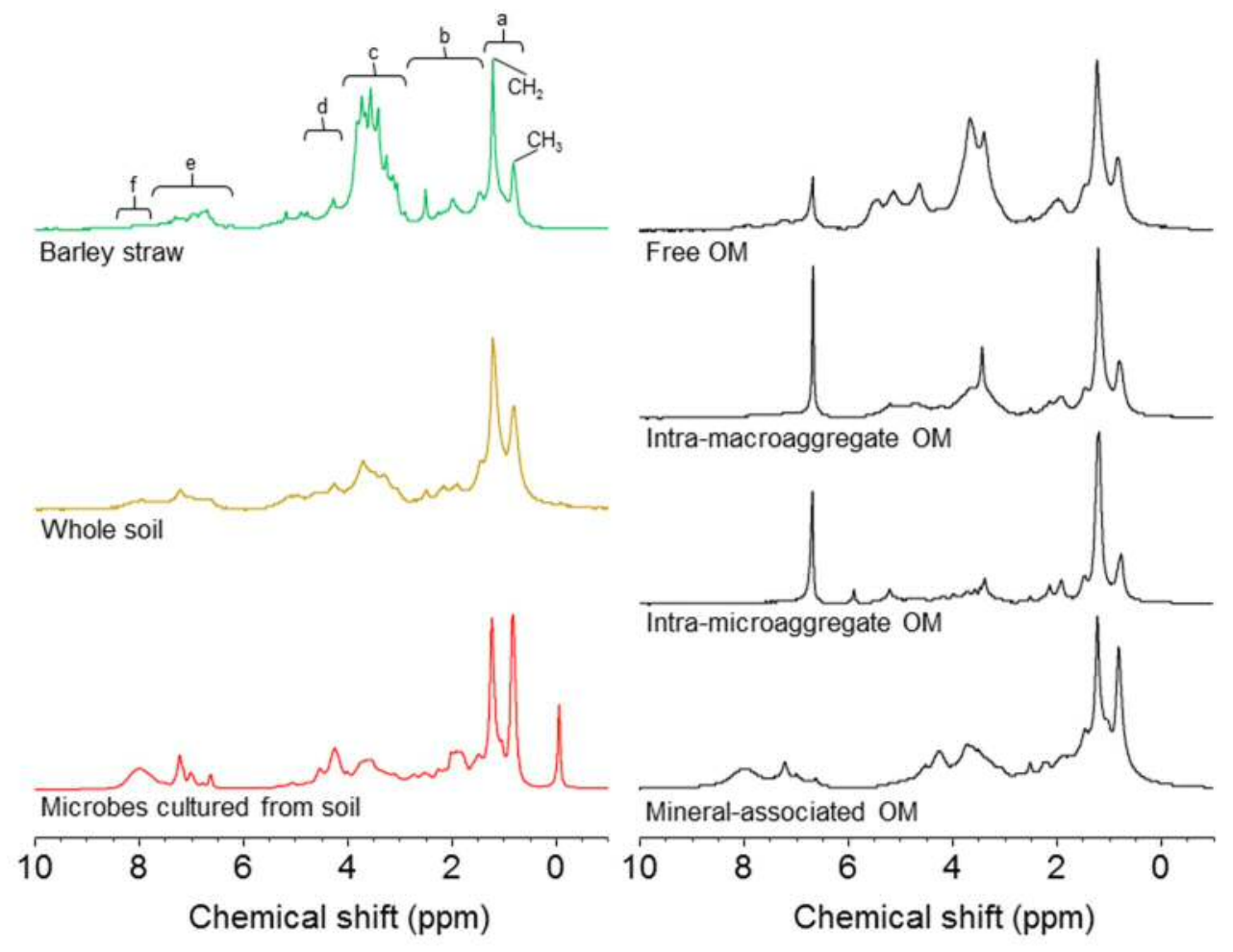

Figure 13. Diffusion edited ${ }^{1} \mathrm{H}$ HR-MAS NMR spectra of microbes cultured from soil, barley straw, semiarid soils under chisel tillage for 25 years, and their respective free, intramacroaggregate, intra-microaggregate, and mineral-associated organic matter (OM) pools. General assignments of chemical shift ranges are as follows: (a) $\mathrm{CH} 3$ and $\mathrm{CH} 2$ (0.6-1.3 ppm); (b) $\mathrm{CH} 3$ and $\mathrm{CH} 2$ near $\mathrm{O}$ and $\mathrm{N}$ (1.3-2.9 ppm); (c) O-alkyl, mainly from carbohydrates and lignin (2.9-4.1 ppm); (d) $\alpha-\mathrm{H}$ from peptides (4.1-4.8 ppm); (e) aromatic, from lignin and peptides (6.2$7.8 \mathrm{ppm})$; and (f) amide in peptides (7.8-8.4 ppm). It is noteworthy that the spectrum of the mineral-associated OM pool is very similar to that of soil microbial cultures, whereas the spectra of the other OM fractions more closely resemble that of barley straw (spectra redrawn from Plaza et al., 2013 and Courtier-Murias et al., 2013 with permission from Elsevier). 